\title{
A Meta-Analysis of the Factors Affecting the Behavior of Auditors to Acceptance of Information Technology
}

\author{
Arash Tahriri * \\ Associate Prof., Department of Accounting, Faculty of Management, University of \\ Tehran, Tehran, Iran. (Corresponding Author) \\ arashtahriri@ut.ac.ir \\ Akram Afsay \\ Ph.D. Candidate, Department of Accounting, Faculty of Management, University of \\ Tehran, Tehran, Iran \\ (a.afsay@ut.ac.ir)
}

\begin{abstract}
:
One of the leading characteristics of accounting profession is its accountability to the public. Unfortunately, occurrence of recent financial crisis has dwindled the trust to accounting profession. Many researchers believe that the destroyed trust can only be recovered by ethical leadership and learning ethics. Therefore, the objective of the present research is to offer a model for ethical competencies' education in accounting profession. The desired model includes three aspects namely recognition of ethical competencies, teaching method, and the accounting course in which the mentioned competencies should be taught. In this research, the required data were gathered in 1398(Iranian year) from the 150 questionnaires which were distributed among accounting elites including accounting lecturers and certified public accountants. Fuzzy Delphi methodology with screening approach is used to analyze the data.

Based on the results, eleven ethical competencies are recognized which should be taught using combinational method separately rather than teaching as a sub-set of an accounting course. In general, it is expected that using the mentioned model for ethical competencies' education in academic environments will familiarize the accounting students with the necessary competencies needed to make ethical decisions. Then, by improving the accounting decision making in workplaces, graduates can pave the way toward public's trust to accounting profession.
\end{abstract}

Keywords: Information technology, auditing, technology acceptance, metaanalys

Copyrights:

This license only allowing others to download your works and share them with others as long as they credit you, but they can't change them in any way or use them commercial. 


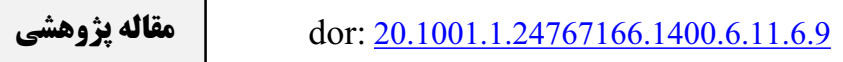

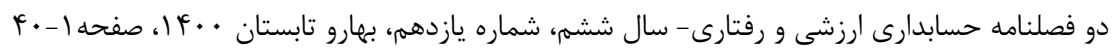

\section{فراتحليل عوامل موثر بر رفتار حسابرسان جمت يذيرش فناورى اطلات

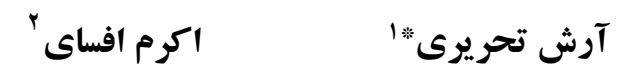

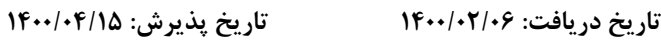

״يشرفت در فناورى و تحول دنياى تجارى امروز، حسابرسان را با קالش منسوخ شدن

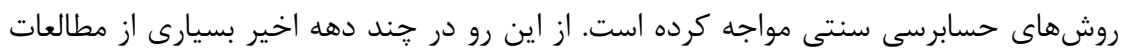

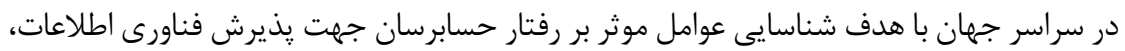

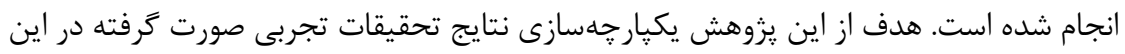

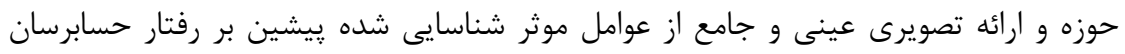

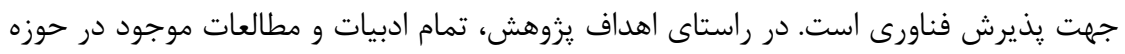

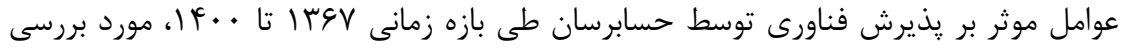

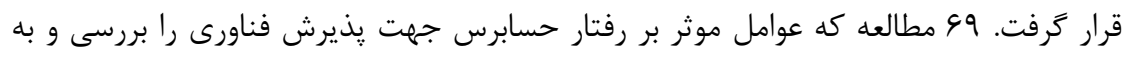

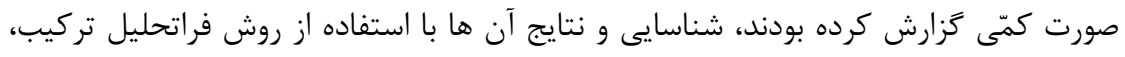

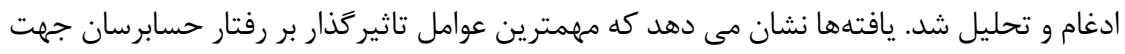

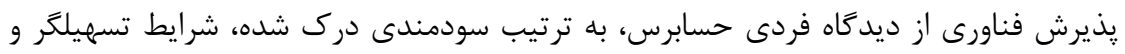

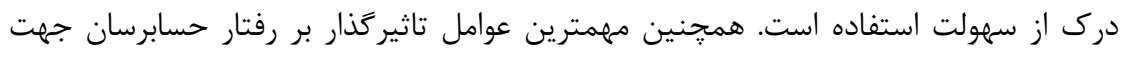

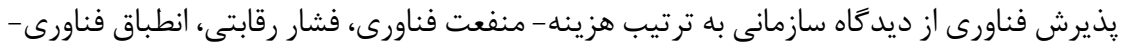

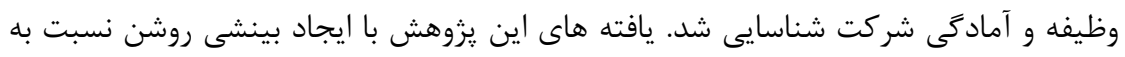

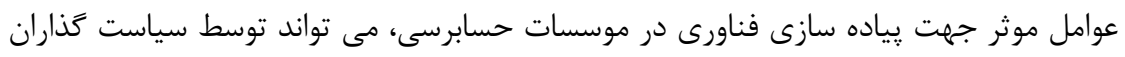

حرفه، شركاء موسسات حسابرسى، شاغلان در حرفه و دانشخاهيان مورد استفاده قرار گيرد.

$$
\text { كليد وازهها: فناورى اطلاعات، حسابرسى، يذيرش فناورى، فراتحليل. }
$$

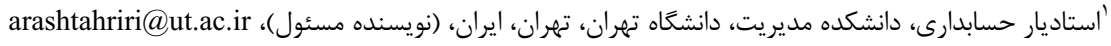

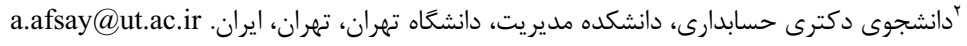


|-مقدمه:

تحولات و ييشرفت ها در فناورى اطلاعات و تكنولوزى هاى جديد تقريباً تمام جنبههاى زندگى

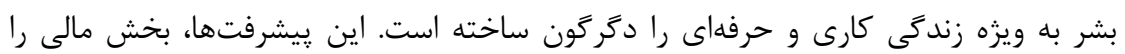
همانند ساير بخشها در نورديده و باعث تحولات و دگر گونىهاى قابل توجهى در حرئ حوزه مالى و

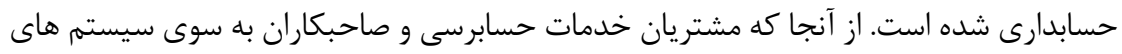
غير كاغذى حذار كردهاند، حرفه حسابرسى نيز به تبع اين تغييرات، براى همعام شدن با تحولات

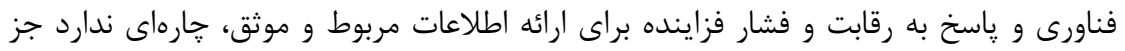

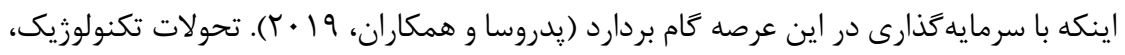
حرفه حسابرسى را با جالش منسوخ شدن روشهاى سنتى مواجه كرده است (روسلى و همكاران،

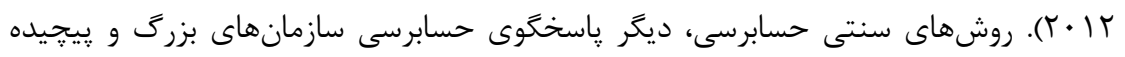

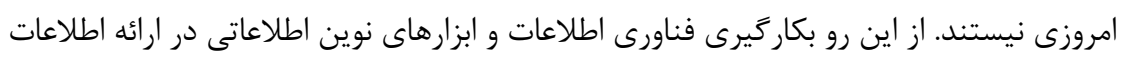

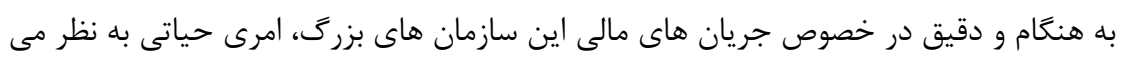

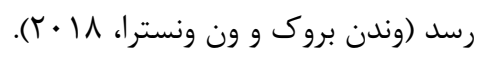

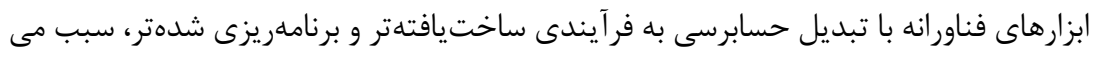
شود حسابرسان قادر به حسابرسى محيطهاى يِيجيده تجارى با ريسك ذاتى بالا شوند كه به ارائه خدمات حسابرسى با درجه بالايى از قضاوت فردى، حرفهاى و تخصصى منجر مى مى شود (كائو و

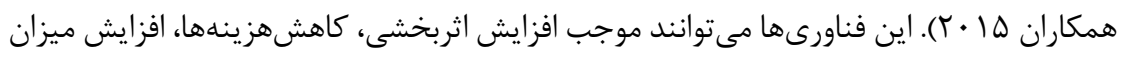
خود كارسازى، كاهش اشتباهات انسانى، بهبود يردازش اطلاعات، كاهش ريسك حسابرسى، بهبود ياسخكويى و كاهش سطح اطلاعات فنى لازم براى انجام كار حسابرسى شود (سيئو و همكاران، 9 19 • (ץ). به علاوه درصورت عدم يذيرش فناورى توسط حسابرسان اين خطر وجود دارد كه ساير بازيخران اقتصادى با ارائه خدمات خود وارد رقابت با موسسات حسابرسى شوند (تيبريوس و و واتون

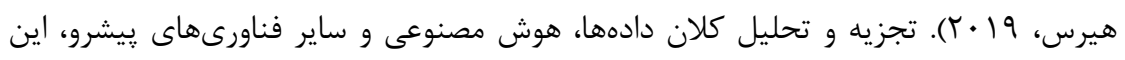
توانايى را دارند كه در آينده روشها و دستورالعمل هاى حسابرسى را مشابه يك همكار انسانى

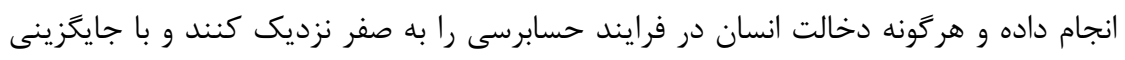
فناورى به جاى حسابرس، تهديدى جدى براى حرفه حسابرسى تلقى گردند. بدين ترتيب ييش نرفتن با فناورىها حتى اگر موجب منسوخ شدن حرفه حسابرسى نشود، ميى تواند در درى آينده

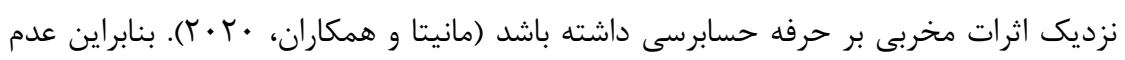

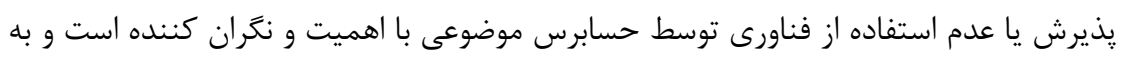
معنى ناتوانى در دستيابى به حسابرسى با كيفيت در دنياى پييجيده امروز است كه اين موضوع 


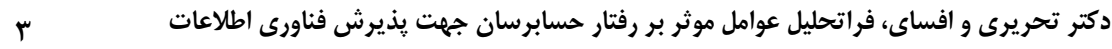

نه تنها به حرفه حسابرسى بلكه به سرمايه كذاران و استفاده كنندگان از اطلاعات حسابدارى نيز

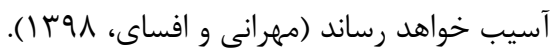

با اين حال و به رغم تمام مزيتهاى ذاتى فناورىهاى جديد و ريسكهاى رهائ ناديده گرفتن اين فناورىها، بكارگيرى فناورى اطلاعات در حرفه حسابرسى مخصوصا در كشورهاى كمتر توسعه يافته و موسسات حسابرسى كوجى آنطوركه بايد توسعه يِدا نكرده و جشمخير نيست (لوو،

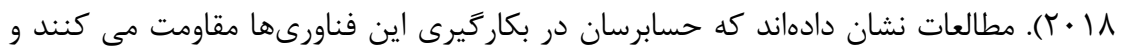
استفاده از فناورى در بسيارى از موسسات حسابرسى، مورد استقبال قرار نمى گيرد. در واقع تاريخ توسعه نرمافزارهاى حسابرسى، شامل يروزههاى زيادى است كه توسط حسابرسان رد شده يا به

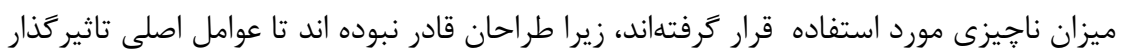
بر رفتار حسابرسان جهت يذيرش فناورى را در نظر بخيرند (يدروساو همكاران، 9 ( •؟). در ياسخ به اين مشكل و براى شناسايى عوامل موثر بر رفتار حسابرسان جهت يذيرش فناورى، طلى سال هاى اخير تعداد فزاينده اى از مطالعات تجربى در حوزه يذيرش فناورى توسط حسابرسان، در نقاط مختلف جهان صورت گرفته است. با اين وجود نتايج مطالعات و ادبيات در اين زمينه،

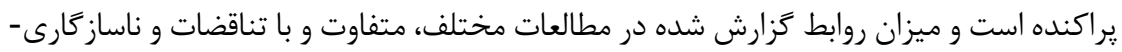

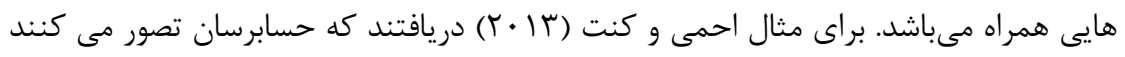
كه ممكن است سرمايه گذارىهاى اوليه جهت بكاركيرى فناورى، در طول عمر فناورى بازيابى نشود و اين ذهنيت در خصوص عدم تطابق هزينه- منفعت باعث مى شود حسابرسان در مقابل

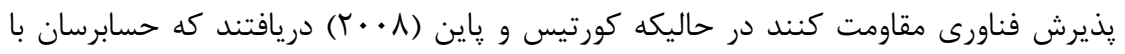
آينده نترى، فناورىهاى حسابرسى را راهى براى كاهش هزينهها در بلند مدت مى دانند.

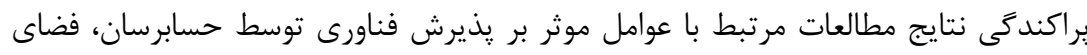
مشخصى را براى تحقيقات اضافى جهت توصيف، تركيب و تلفيق تمام اطلاعات موجود در اختيار كذاشته است كه نتايج اين تركيب و تلفيق، منجر به درك بيشتر از عوامل موثر بر يذيرش فناورى در حسابرسى مى گردد و زمان مورد نياز براى مطالعه اين يديده در ادبيات را كاهش مى مدهد. با

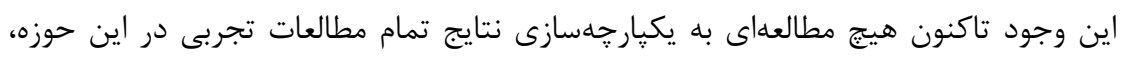

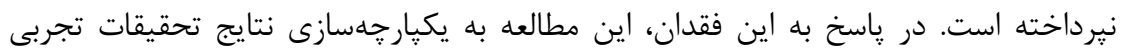
مختلف در محيطهاى متفاوت و ارائه تصويرى عينى و جامع از عوامل موثر شناسايى شده پيشين بر رفتار حسابرسان جهت يذيرش فناورى مى ميردازد.

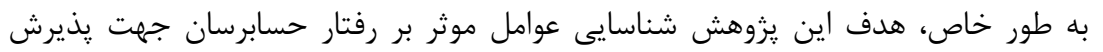
فناورى است كه در راستاى برآورده كردن اين هدف از نتايج تحقيقات صورت گرفته ييشين بهره مى گيرد. از آنجا كه اين حوزه تحت سلطه رويكردهاى تحقيق كمى قرار گرفته است، اين يزوهش 
از روش شناسى فراتحليل بهره برده و حجم زيادى از نتايج با هم ادغام شده است تا مشخص

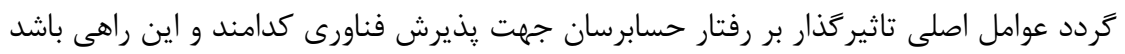

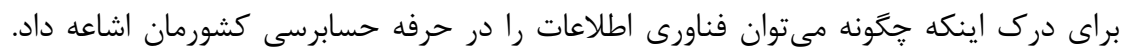

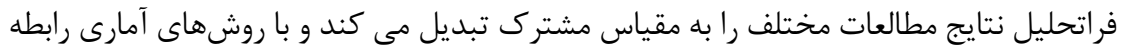

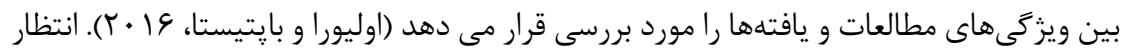
مىرود با انجام فراتحليل، ضمن ايجاد بينشى روشن نسبت به عوامل موثر بر رفتار بردار حسابرس

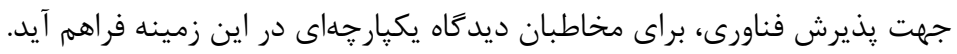

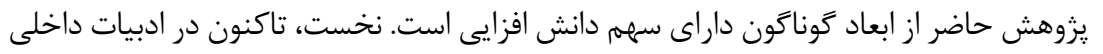

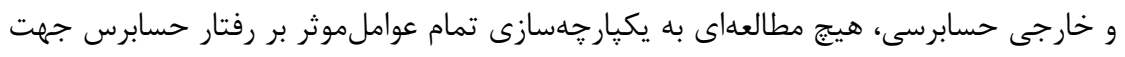

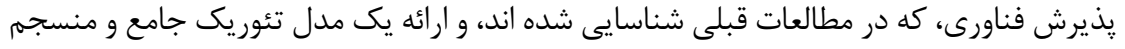

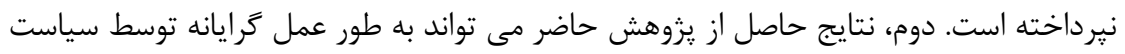

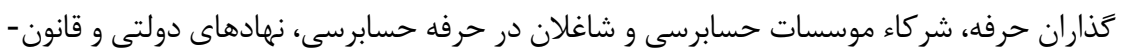

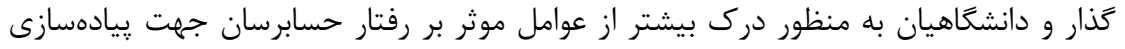

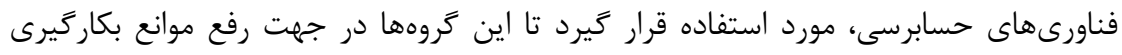

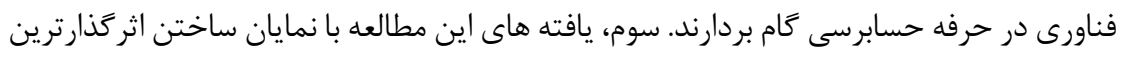
عوامل موثر بر يذيرش فناورى توسط حسابرسان در كشورهاى در حال توسعه، از جمله ايران،

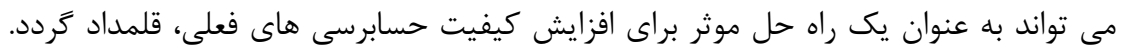

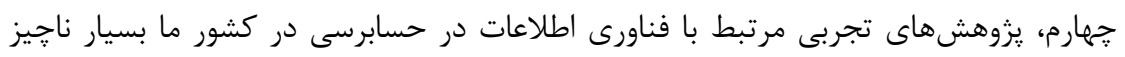

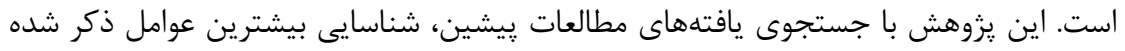

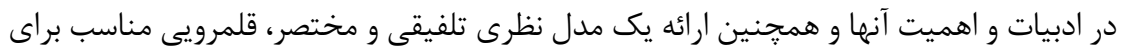

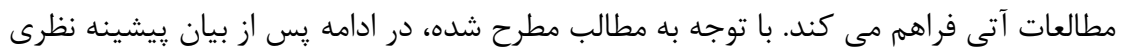

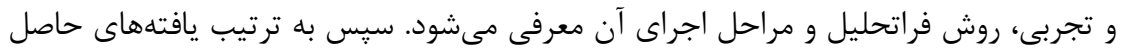

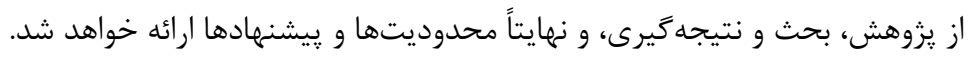

\section{r- مبانى نظرى و بِيشينه يزوهش فناورىهاى حسابرسى}

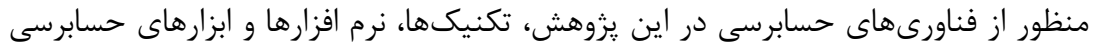

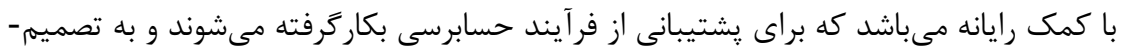

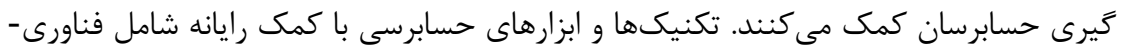
هايى همجون كاربركَهاى حسابرسى الكترونيك، نرم افزارهاى حسابرسى هوشمند و برنامهاى 


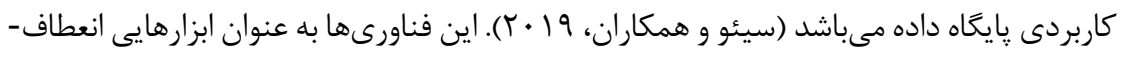

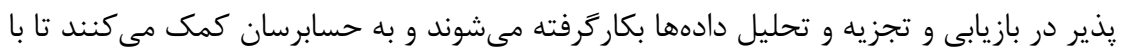

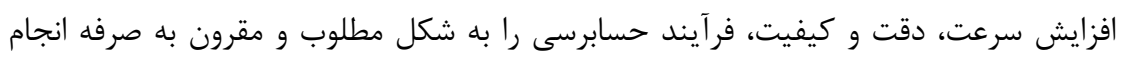

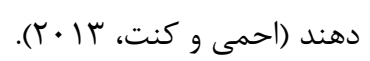

\section{تئورىهاى يذيرش فناورى}

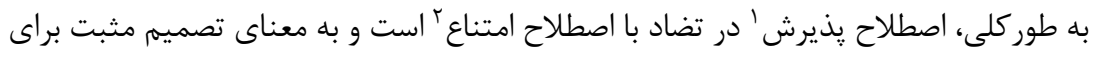

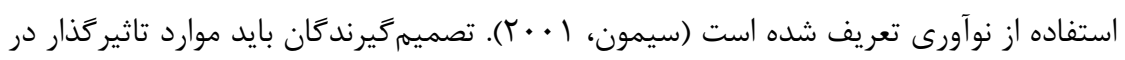

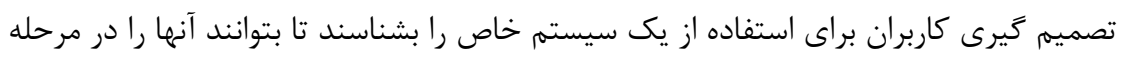

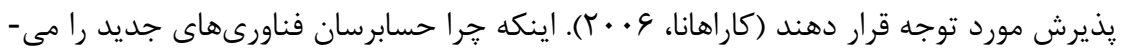

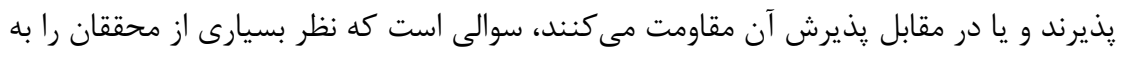

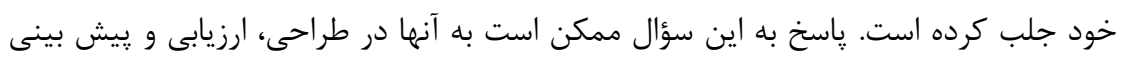

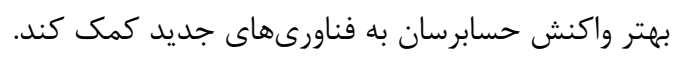

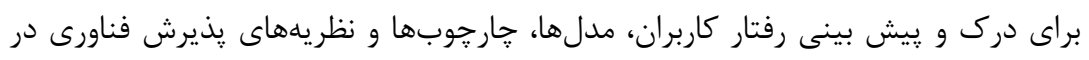

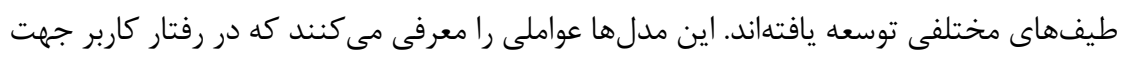

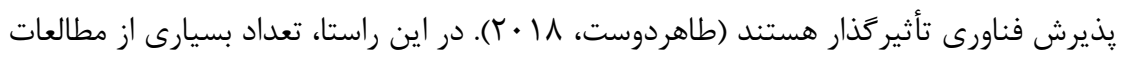

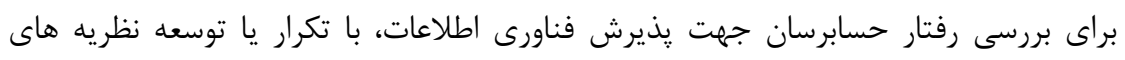

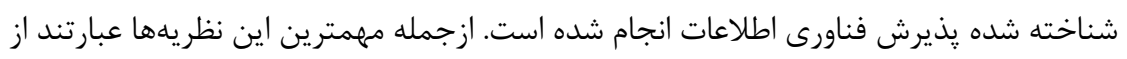

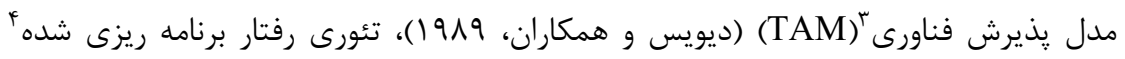

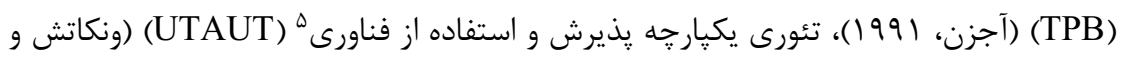

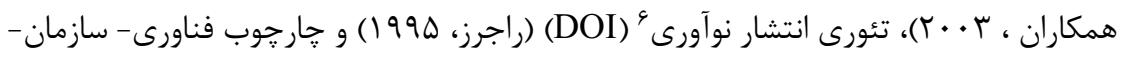

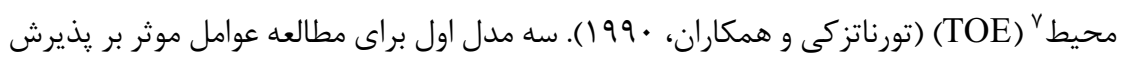

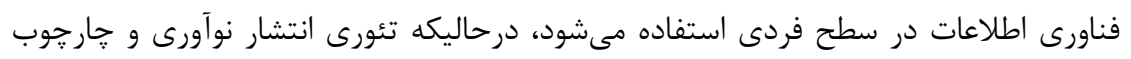

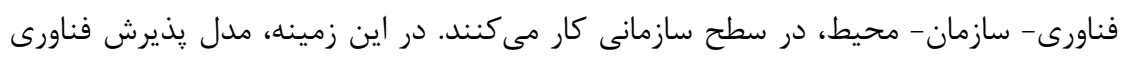

\footnotetext{
${ }^{1}$ Acceptance

${ }^{2}$ Refusal

${ }^{3}$ Technology Acceptance Model (TAM)

4 Theory of Planned Behavior (TPB)

${ }^{5}$ Unified Theory of Acceptance and Use of Technology (UTAUT)

${ }^{6}$ Diffusion of Innovations Theory (DOI)

${ }^{7}$ Technology-Organization-Environment Framework (TOE)
} 
(شكل () يكى از مدلهاى شناخته شده براى توضيح قصد استفاده از يك فناورى است. بسيارى

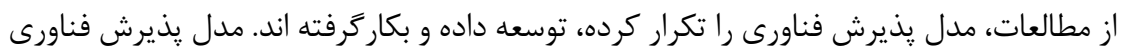

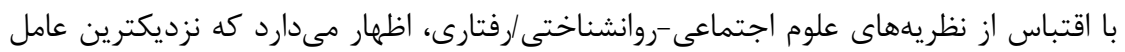

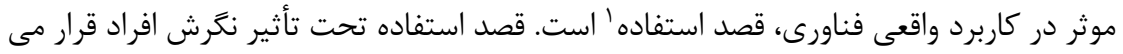

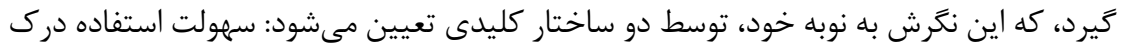

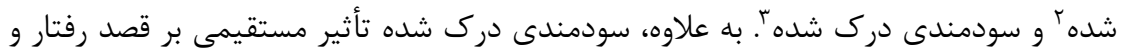

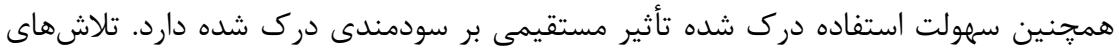

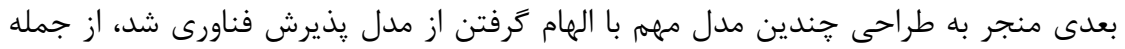

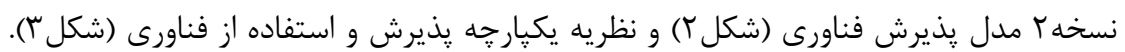

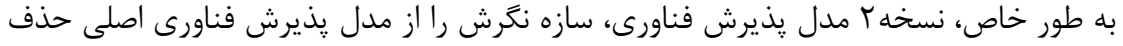

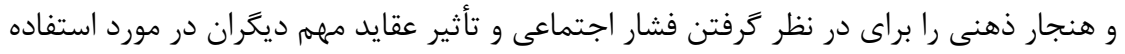

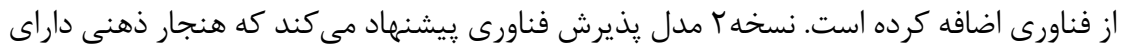

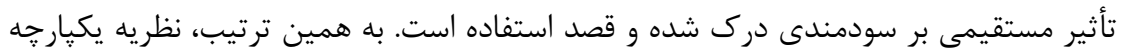

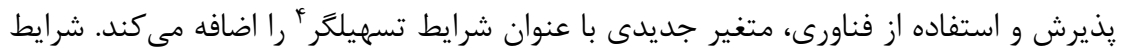

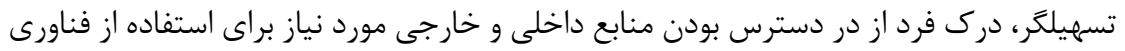

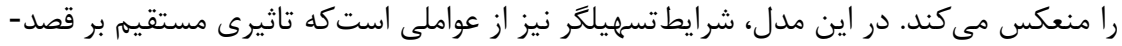

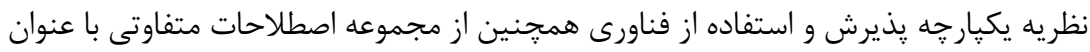

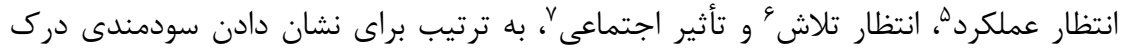

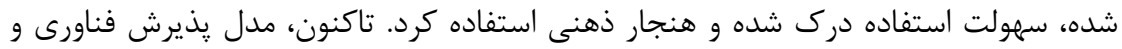

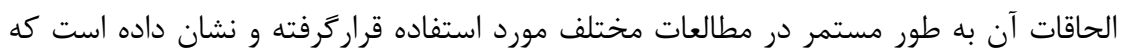
مى تواند عوامل موثر بر رفتار كاربر جهت يذيرش فناورى در زمينه حسابرسى را توضيح دهد.

\footnotetext{
${ }^{1}$ Intention to use

${ }^{2}$ Perceived ease of use

${ }^{3}$ Perceived usefulness

${ }^{4}$ Facilitating conditions

${ }^{5}$ Performance expectancy

${ }^{6}$ Effort expectancy

${ }^{7}$ Social influence
} 
تورناتزكى و فليسجر (•199) حارجوب فناورى- سازمان- محيط (شكله) را براى تصميم

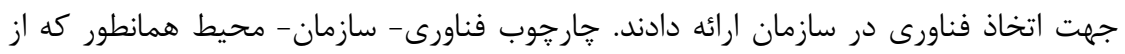

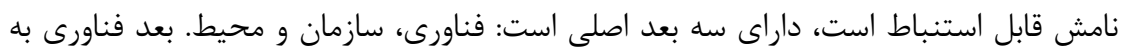
در دسترس بودن و ويزگى هاى فناورى اشاره دارد. بعد سازمانى شامل اقدامات توصيفى درباره

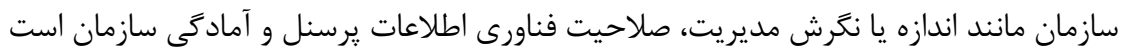

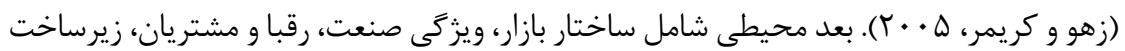
هاى كلان جهت حمايت تكنولوزى و مقرارت حرفهاى و دولتى است (تورناتزكى و فليسجر،

شكل (. مدل يذيرش فناورى (TAM). (ديويس و همكاران، 919 ())

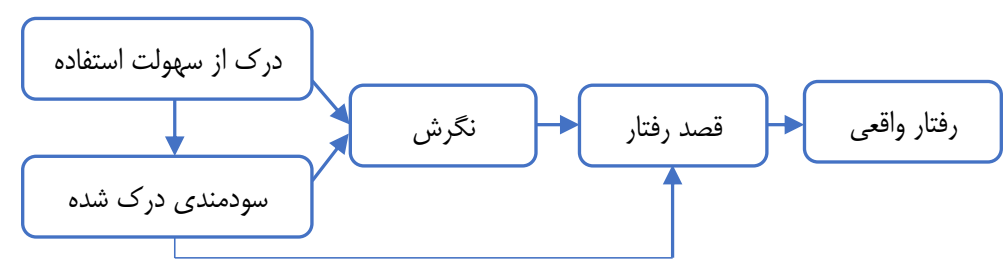

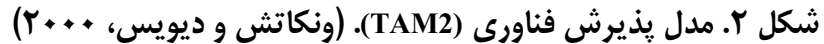

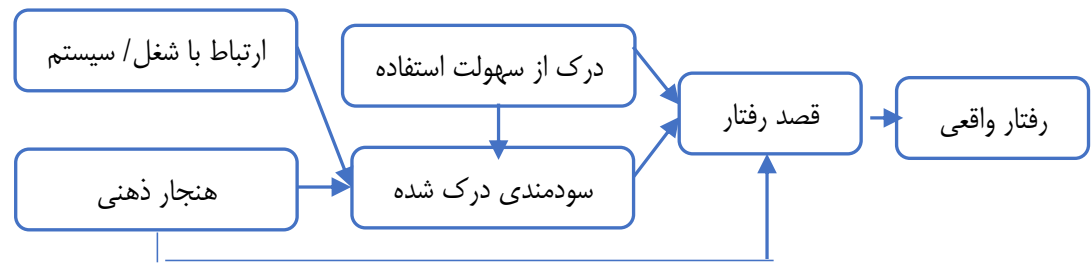

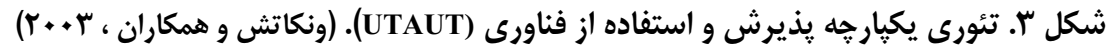

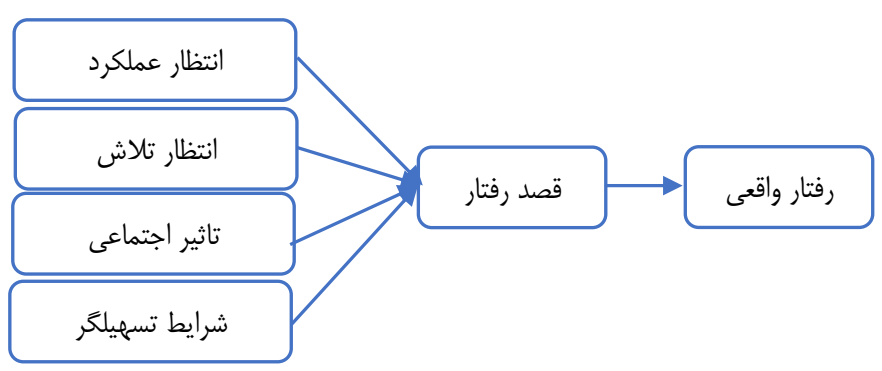


دو فصلنامه حسابدارى ارزشى و رفتارى، سال ششه، شماره يازدهم، بهار و تابستان + +ع إ

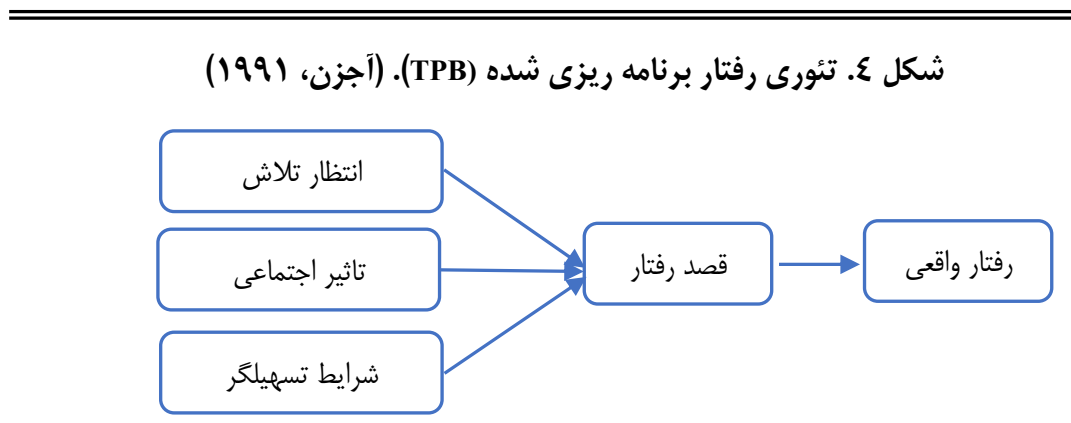

شكل 0. جار جوب فناورى - سازمان- محيط (TOE). (تورناتزكى و همكاران، +999)

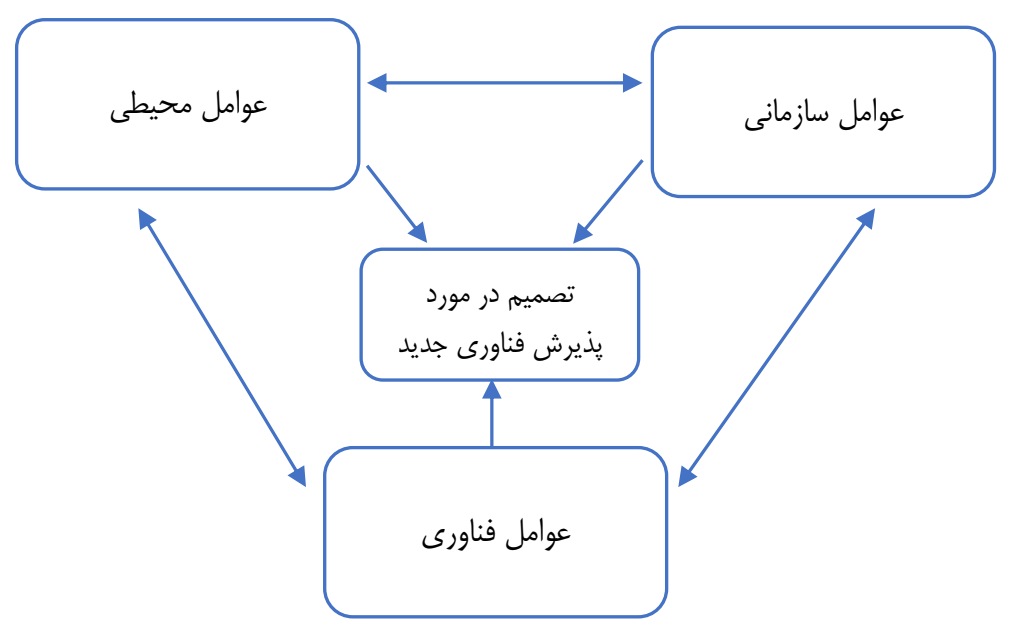

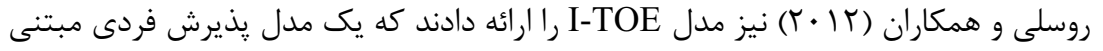

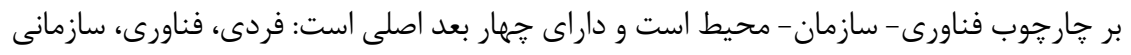

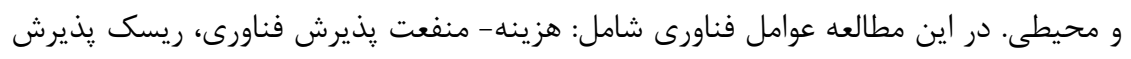

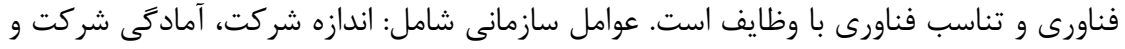

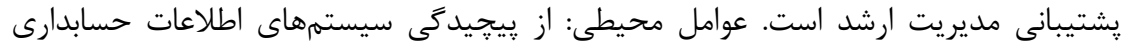

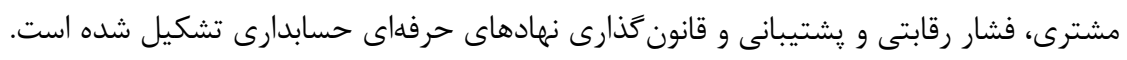
در ادامه تعاريف و يافتههاى يزوهشى مرتبط با عوامل اصلى مطرح شده در مدلهار مانى مذكور بيان 
سودمندى درك شده (انتظار عملكرد)، ميزان درك كاربر نسبت به اين موضوع است كه

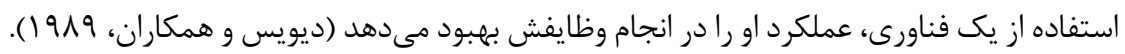

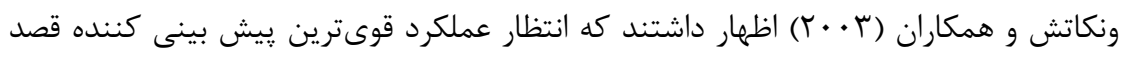

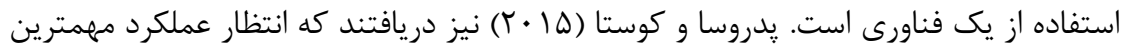

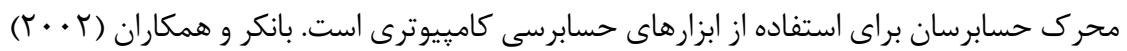

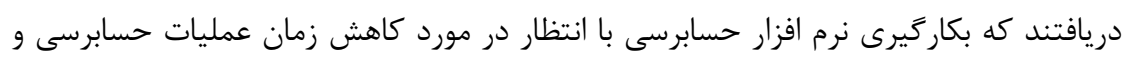

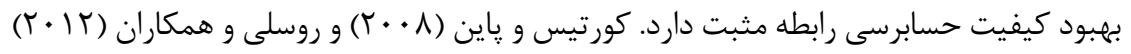

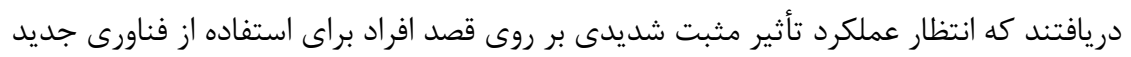
در فعاليت هاى حسابرسى دارد.

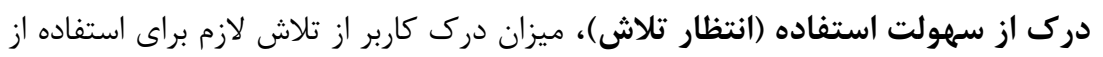

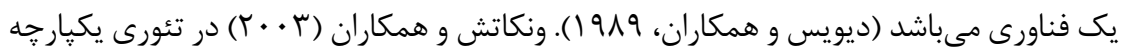

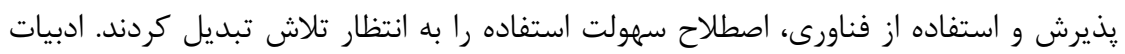

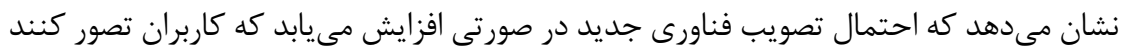

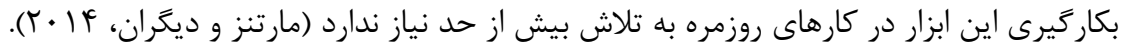

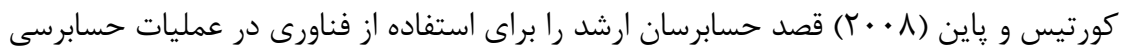

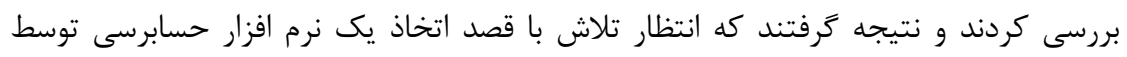

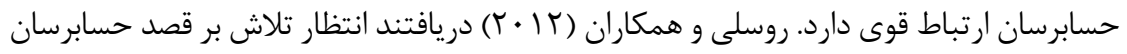

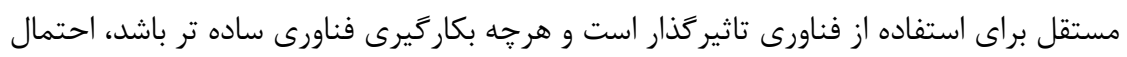
يذيرش فناورى بيشتر است.

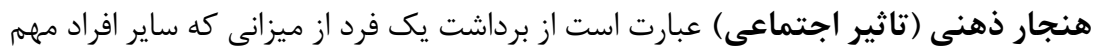

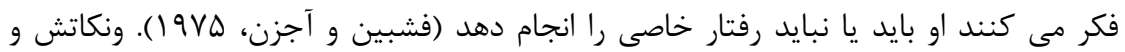

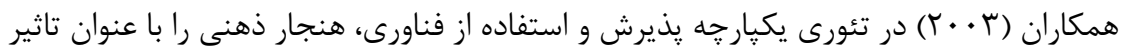

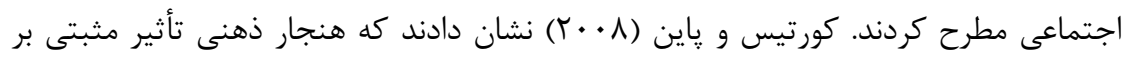

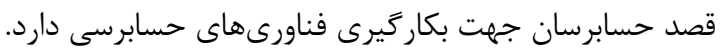

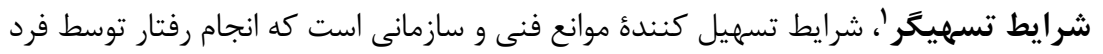

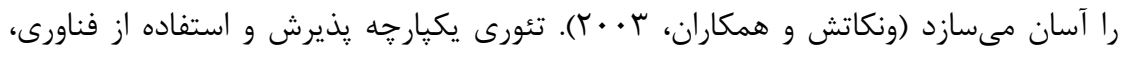

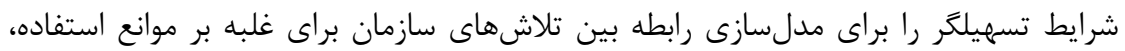

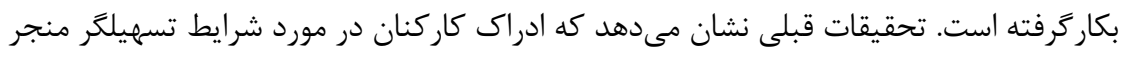

\footnotetext{
${ }^{1}$ Facilitating conditions
} 


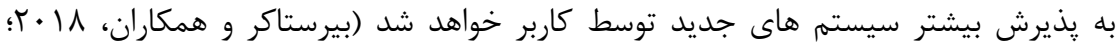

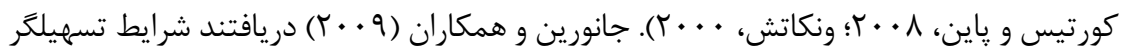

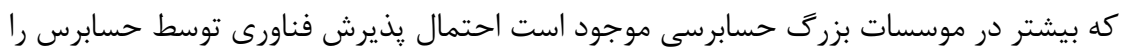

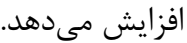

هزينه- منفعت فناورى' عبارت است از مزاياى قابلدرى تعريف شده حاصل از بكارگيرى

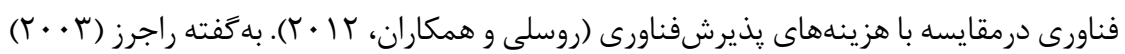

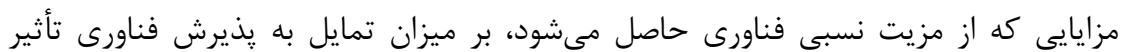

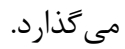
مطابقت فناورى - وظيفه ؟ به ميزان ساز حارى فناورى با نيازهاى حسابرس و مطابقت با وظايف

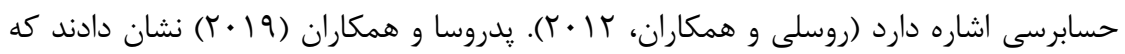

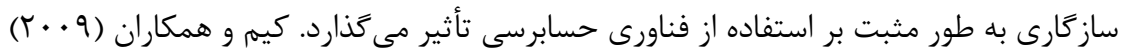

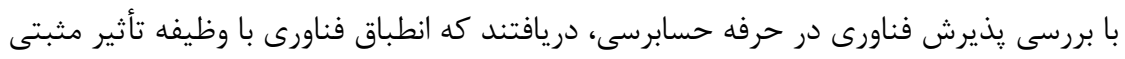

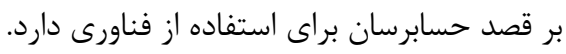

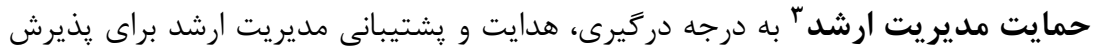

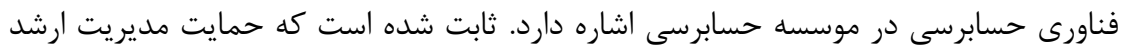

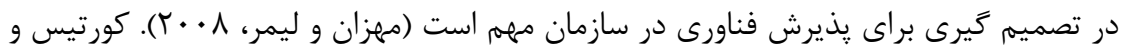

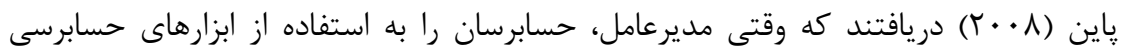

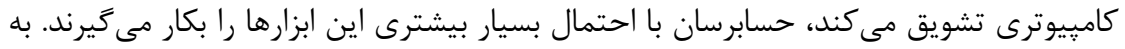

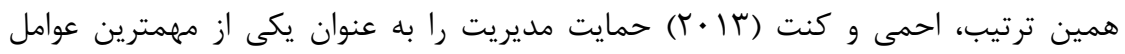
تأثير كذار بر تصميم حسابرسان جهت استفاده از نرم افزارهاى حسابرسى شناسئ

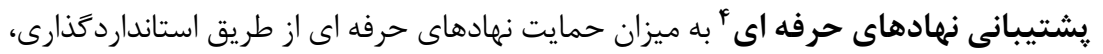

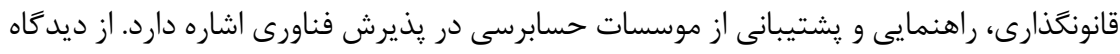

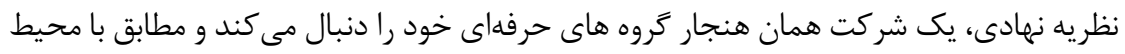

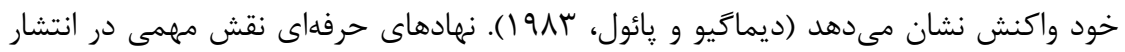

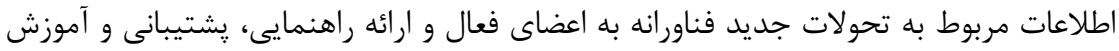

${ }^{1}$ The cost-benefit of technology

${ }^{2}$ Technology-task matching

${ }^{3}$ Company readiness

${ }^{4}$ Top management support 


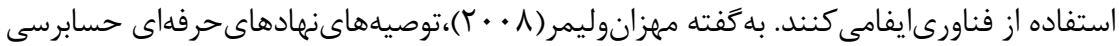

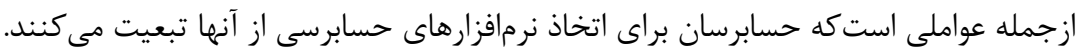

\section{بيشينه يزوهش هاى خارجى}

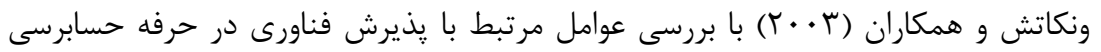

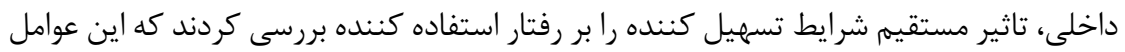
از طريق جنسيت، سن، تجربه و اختيار تعديل مى شوند. آنها دريافتند در حسابرسى دادئ داخلى،

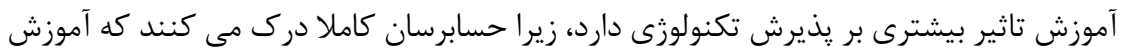

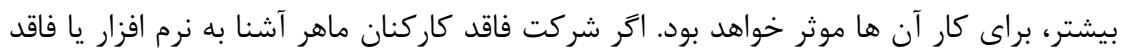
كاركنان فناورى اطلاعات باشد، از تكنولوزى ها استفاده نمى شود.

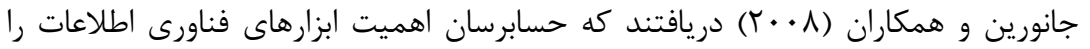

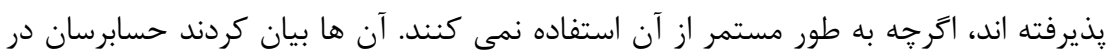

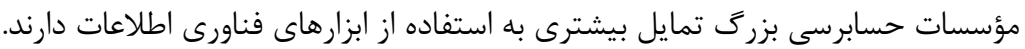

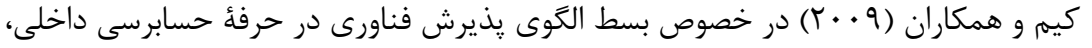

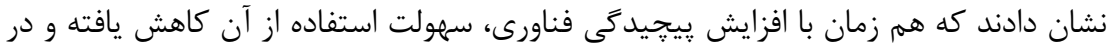
نتيجه استفاده از فناورى كاهش مى يابد نماند

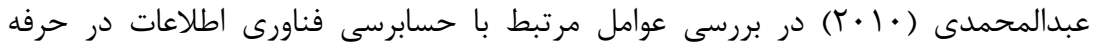

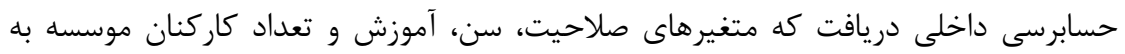
صورت مثبت و با اهميتى با ميزان زمان صرف شده بوسيله حسابرسان براى حسابرسى فناورى اطلاعات رابطه دارد، اما سطح تحصيلات و كشور محل اقامت روى نتايج تاثيرى ندارد.

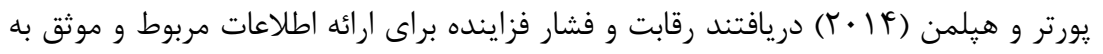

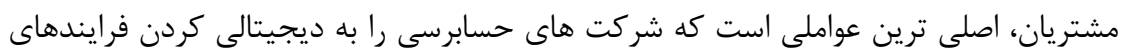
خود سوق مى دهد.

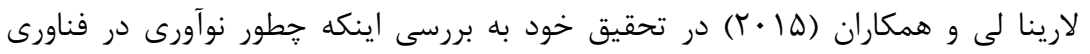
اطلاعات مىتواند در كاهش ريسك كلى فرايند حسابرسى و ريسك كسبو كار ارزش آفرينى كنى كند،

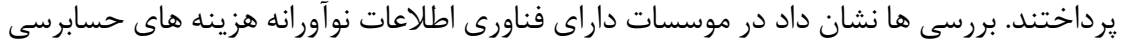

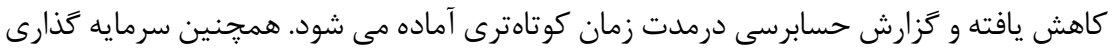

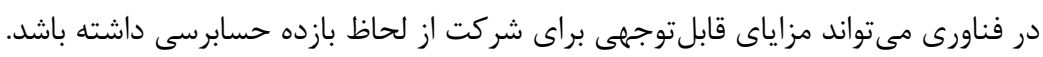

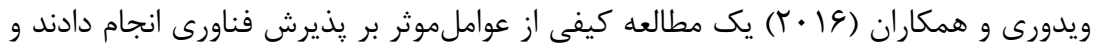
يشتيبانى نهادهاى حرفهاى حسابدارى را به عنوان يكى از مهمترين عوامل شناسايى كردند. 


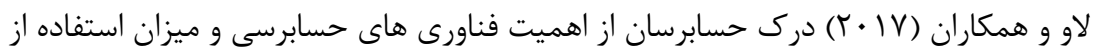

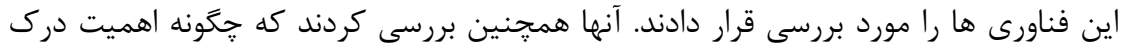

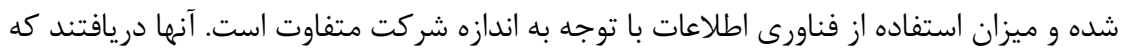

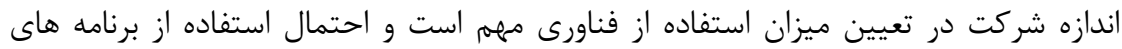
حسابرسى فناورى اطلاعات در شركتهاى بزرى بـ بيشتر است.

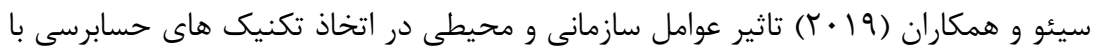
كمك كامييوتر' توسط موسسات حسابرسى در كشورهاى كمتر توسعه يافته مانند مالزى راني

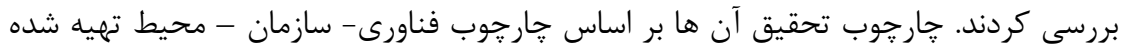

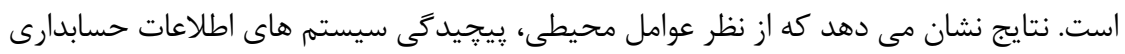
مشترى و سطح حمايت نهادهاى حرفه اى حسابدارى بر اتخاذ فناورىهاى حسابرسى تاثير كذار

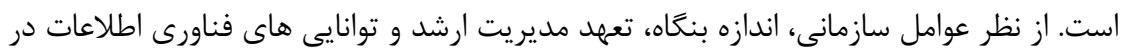

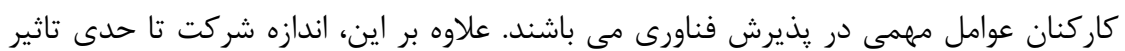

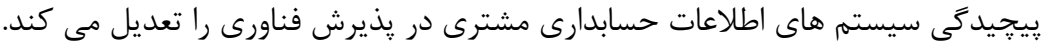

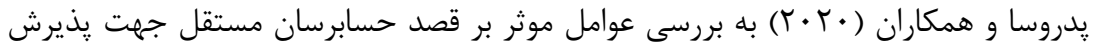

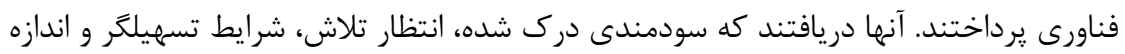
موسسه حسابرسى عوامل اصلى يذيرش و استفاده از فناورى هاى حسابرسى هستند.

\section{يبشينه يزوهش هاى داخلى}

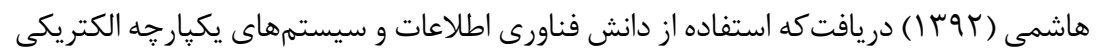
براى امر حسابرسى باعث افزايش كيفيت عملكرد و توانمندسازى كاركنان حسابرسى خواهد شداندا

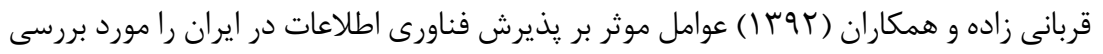

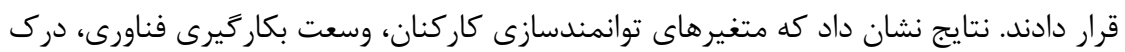

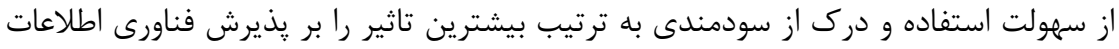

در موسسات داشته اند.

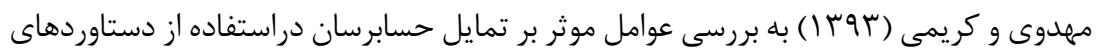

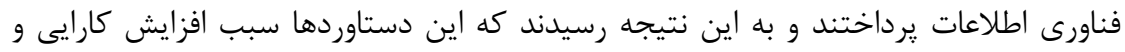

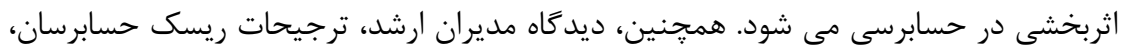

\footnotetext{
${ }^{1}$ computer-assisted auditing techniques (CAATs)
} 


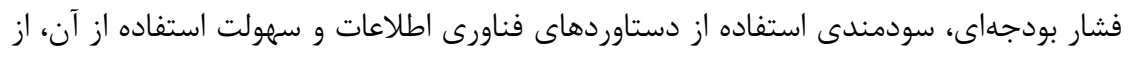

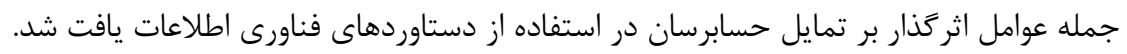

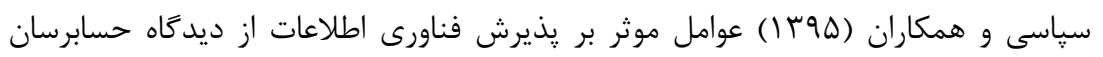

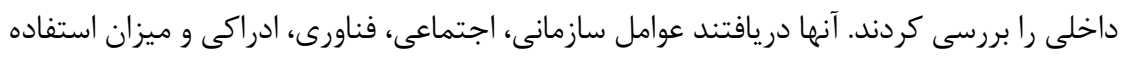

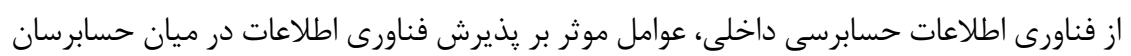

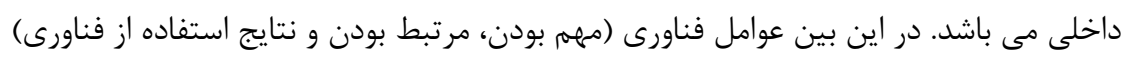
مهمى ترين عوامل مى باشد.

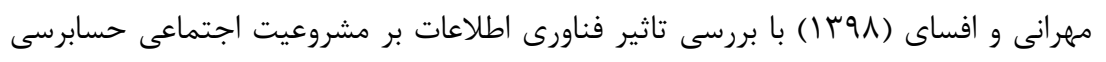

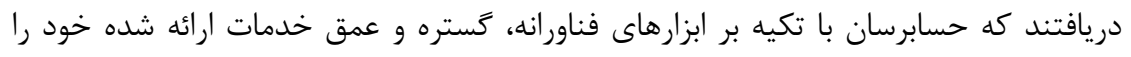

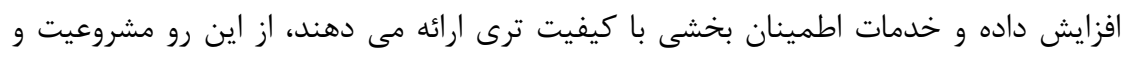

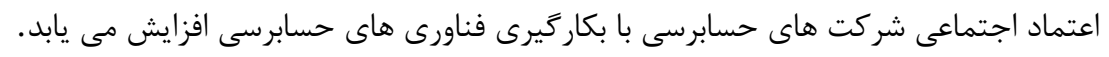

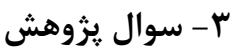

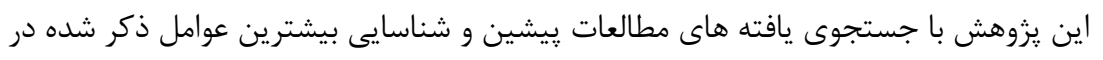

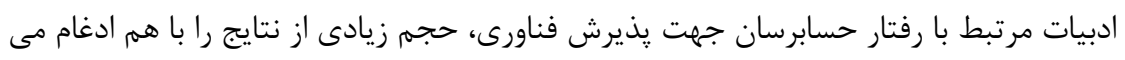

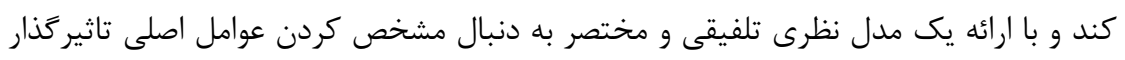

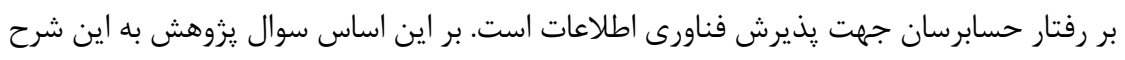

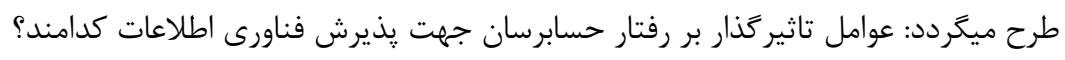

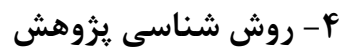

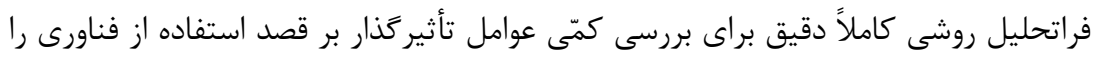

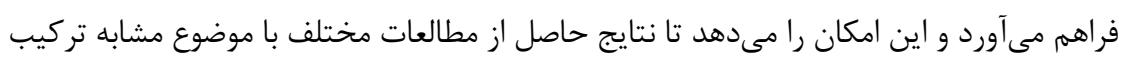

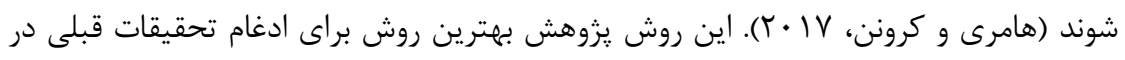

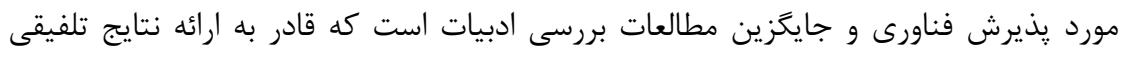

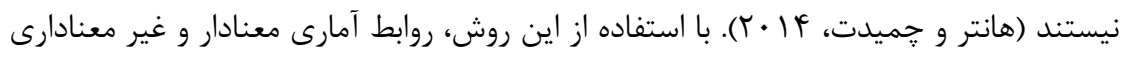

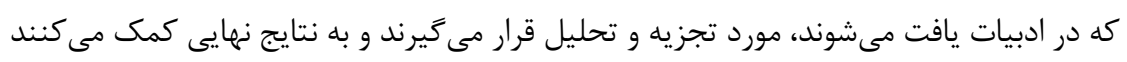

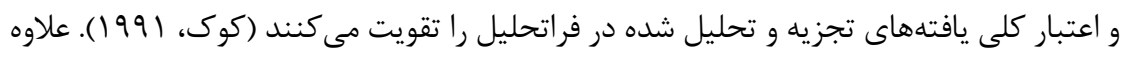

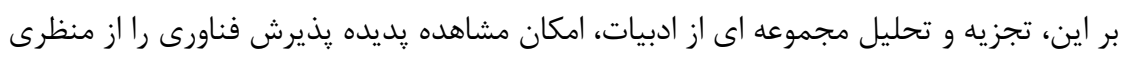

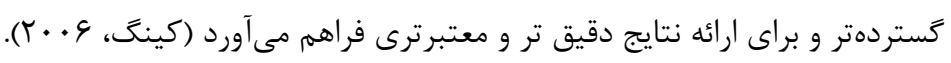




\section{جامعه و نمونه يزوهش}

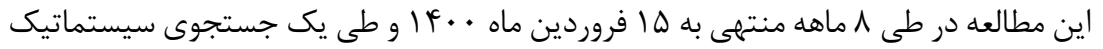
ادبيات در يايخاههاى الكترونيكى مطالعات علمى شامل Scopus، Science Direct، ProQuest Google Scholar و Elsevier ،SSRN ،Springer ،Emerald ،

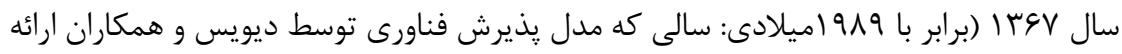

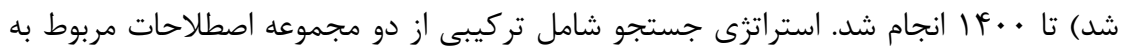

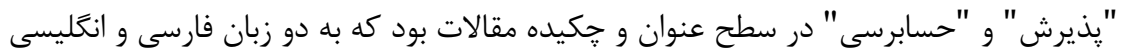

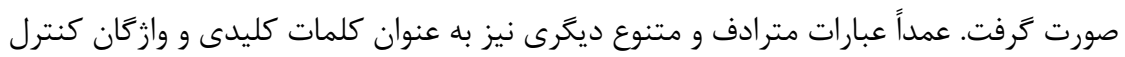

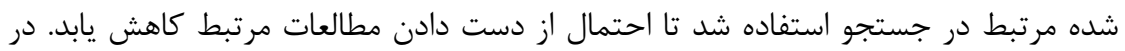
جدول ا كليدوازه هاى اصلى مورد جستجو ارائه شده است.

\begin{tabular}{|c|}
\hline جدول ا. كليد وازه هاى اصلى مورد جستجو \\
\hline : Audit + technology $\}:\{$ Audit + diffusion $\} \subseteq\{$ Audit + Adoption $\} \subseteq\{$ Audit + Acceptance $\}$ \\
\hline$؛\{$ Audit + TPB $\}:\{$ Audit+DOI $\}:\{$ Audit+TOE $\}:\{$ Audit+UTAUT $\}:\{$ Audit+TAM $\}$ \\
\hline 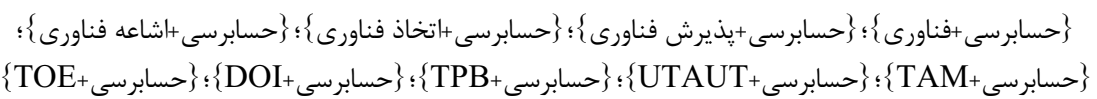 \\
\hline
\end{tabular}

مطالعاتى كه عناوين آنها در جستجوى اوليه مرتبط تشخيص داده شد، با مطالعه جكيده مورد

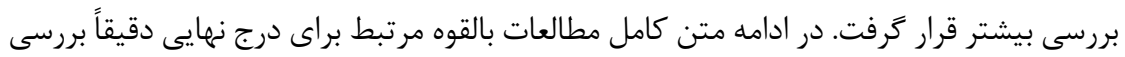

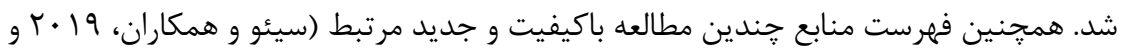

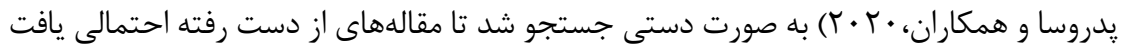

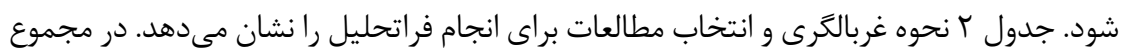

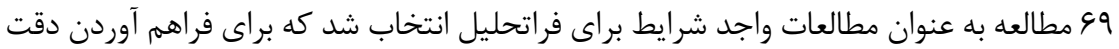

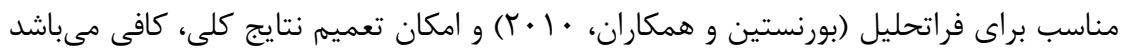

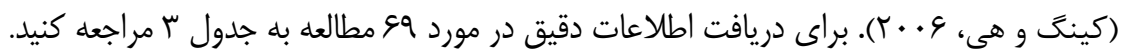

\begin{tabular}{|c|c|}
\hline \multicolumn{2}{|r|}{ جدول r. نحوه انتخاب مطالعات براى انجام فراتحليل } \\
\hline DFT & تعداد مطالعات اوليه \\
\hline & معيارهاى حذف مطالعات: \\
\hline$\left(1 / l^{f}\right)$ & مطالعاتى كه با موضوع يا روش يروهش منطبق نبودند \\
\hline$($ (rYq) & مطالعاتى كه ضريب تبديل يذير به اندازه اثر را ززارش نكرده بودند \\
\hline$(r I)$ & مطالعاتى كه از اعتبار كافى برخوردار نبودند \\
\hline 99 & تعداد نهايى مطالعات مورد استفاده \\
\hline
\end{tabular}


جدول r. ليست مطالعات بكاركرفته شده در فراتحليل

\begin{tabular}{|c|c|c|c|c|}
\hline عنوان مقاله & كشور & 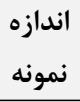 & 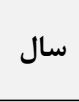 & نويسنده (كان) \\
\hline تأثير آموزش در يذيرش حسابرسان از يك سيستم كار & 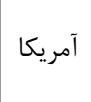 & rی9 & $r \cdot r$ & بدارد و همكاران \\
\hline 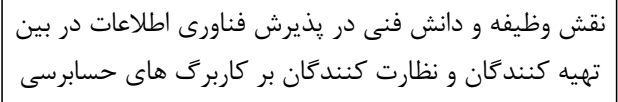 & 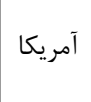 & lar & $r \cdot r$ & بدارد و همكاران \\
\hline 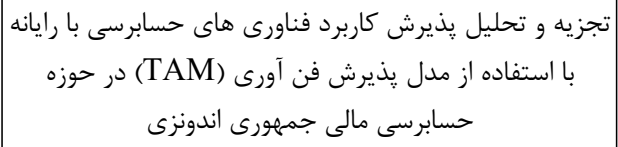 & اندونزى & rی & $r \ldots r$ & 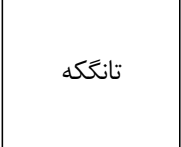 \\
\hline بررسى عوامل زمينه اي و خصوصيات فردى موثر بر تصميمات & 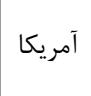 & 149 & $r \cdot . q$ & كورتيس و پاين \\
\hline توسعه مدل حسابرسى مبتنى بر فناورى & 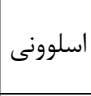 & $v F$ & $r \cdot r$ & دولينسك و \\
\hline يذيرش روش هاى حسابرسى با كمك رايانه توسط حسابرس & 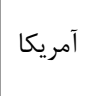 & 111 & $r \cdots \wedge$ & 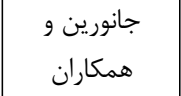 \\
\hline 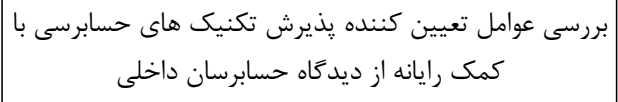 & 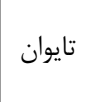 & $11 \mathrm{~V}$ & $r \cdots \wedge$ & هانگ و همكاران \\
\hline 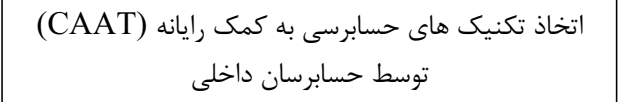 & 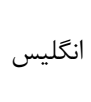 & $9 \Delta$ & $r \cdot \Lambda$ & 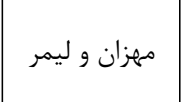 \\
\hline استفاده از سيستم اطلاعات يشتيبان حسابرسى: تأثير & استراليا & $\Delta \& 9$ & $r \cdot . q$ & دولينَ \\
\hline بررسى استفاده از فناورى اطلاعات حسابرسى و اهميت درى & 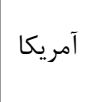 & $|1|$ & $r \cdot . q$ & 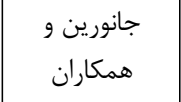 \\
\hline يذيرش فناورى اطلاعات در حرفه حسابرسى داخلى: تأثير & 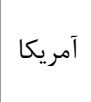 & $1 \wedge \Delta$ & $r \cdot . q$ & 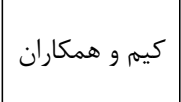 \\
\hline مدل اشاعه فناورى اطلاعات در شركت هاى حسابرسى كوجى در تايلند & 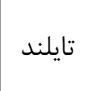 & VT & $r \cdot l \cdot$ & يونَّياتراجى \\
\hline
\end{tabular}


دو فصلنامه حسابدارى ارزشى و رفتارى، سال ششم، شماره يازدهم، بهار و تابستان ++ع|

\begin{tabular}{|c|c|c|c|c|}
\hline كاربرد مدل يذيرش فناورى در بكاركيرى نرم افزار حسابرسى حسابرسان & 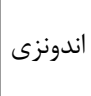 & 99 & $r \cdot 1$. & 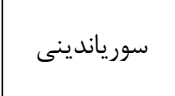 \\
\hline 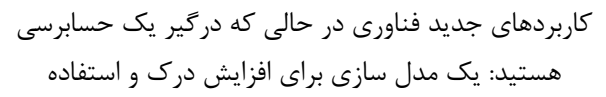 & 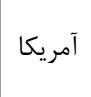 & 99 & $r \cdot l \cdot$ & 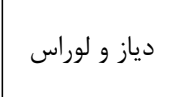 \\
\hline 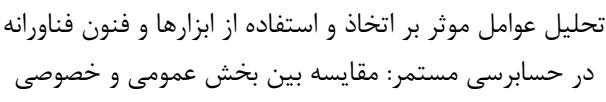 & اسيانيا & er & $r \cdot 11$ & بانسون و بوررو \\
\hline 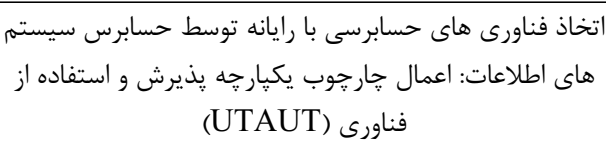 & جنوبى آن آ & $11 \cdot$ & $r \cdot 11$ & 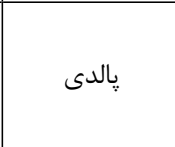 \\
\hline تجزيه و تحليل ويرگكى هايى كه بر يذيرش نرم افزار حسابرسى & 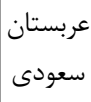 & $\Delta \omega$ & $t \cdot i t$ & 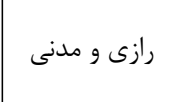 \\
\hline 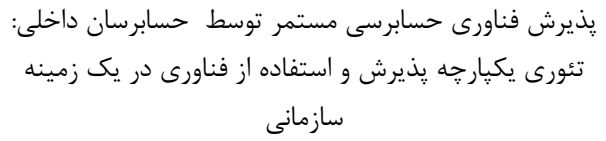 & 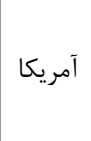 & TMY & $t \cdot i t$ & كمونزالس و \\
\hline دستاوردهاى فناورى اطلاعات مايل حسابرسان نسبت بداه حسابه استفاده از & ايران & TET & $t \cdot i t$ & مهدوى و كريمى \\
\hline يذيرش فناورى حسابرسى در موسسات حسابرسى & 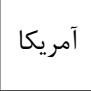 & r人 & $r \cdot 14$ & 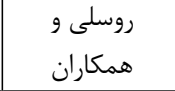 \\
\hline استفاده از نرم افزار حسابرسى عمومى (GAS) توسط حسابرسان مستقل & انخَلستان & $r \cdot \Delta$ & $r \cdot 14$ & احمى و كنت \\
\hline 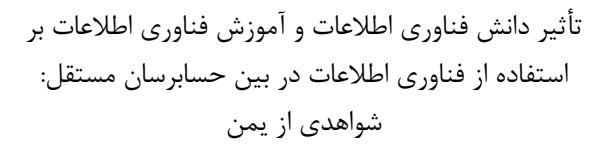 & 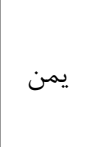 & 198 & $r \cdot 14$ & على آل انسى و \\
\hline 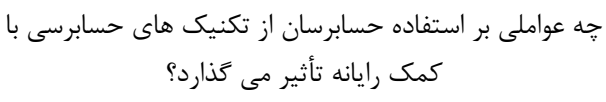 & 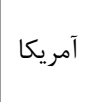 & 111 & $r \cdot 14$ & بيرستاكر و \\
\hline 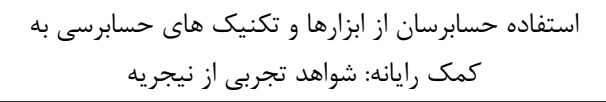 & نيجريه & $t \cdot t$ & $r \cdot 14$ & ابيموبويى \\
\hline 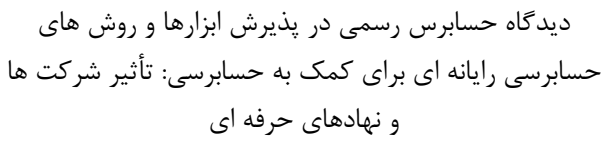 & 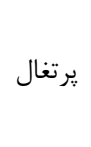 & $11 \cdot$ & $r \cdot 14$ & يدروسا و كوستا \\
\hline
\end{tabular}




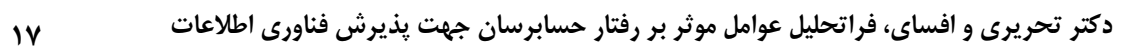

\begin{tabular}{|c|c|c|c|c|}
\hline مدل سازى تصميمات استفاده داوطلبانه از فناورى در & 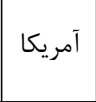 & $\vee \Delta$ & $r \cdot 1 f$ & كورتيس و پاين \\
\hline تورابع و ويزگى هاى داخى داخلى نرم افزار تجزيه و تحليل داده ها: & نيجريه & 109 & $r \cdot 14$ & تيجانى \\
\hline راهكارهاى استفاده از حسابرسى فناورى اطلاعات و درك از & 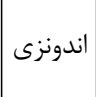 & $\uparrow \&$ & $r \cdot 14$ & كريسوارا \\
\hline 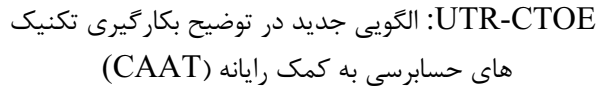 & 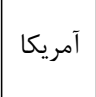 & $\Delta \wedge 1$ & $r \cdot 10$ & رامن و همكاران \\
\hline 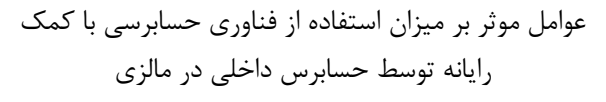 & 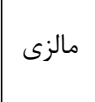 & $1 \cdot 1$ & $r \cdot 10$ & شمسودى و \\
\hline انخَيزه ها و محدوديت هاى استفاده از فناورى اطلاعات در كار & 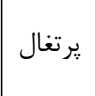 & $11 \cdot$ & $r \cdot 10$ & 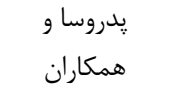 \\
\hline تاثير جنبه هاى فنى، سازمانى و محيطى در يذيرش فناورى & مالزى & 199 & $r \cdot 19$ & 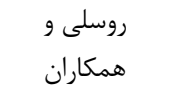 \\
\hline عوامل موثر در يذيرش تكنيك هاى حسابرسى به كمك رايانه & 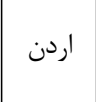 & $r \cdot$. & $r \cdot 19$ & 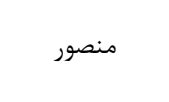 \\
\hline اتخاذ نرم افزار حسابرسى عمومى: ديدكاه اندونزيايى & 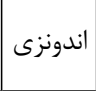 & IrF & $r \cdot 19$ & ويدورى و \\
\hline استفاده از نرم افزار حسابرسى عمومى توسط حسابرسان & مصر & 111 & $r \cdot 19$ & كيم و همكاران \\
\hline مطالعه نكَرش حسابرس در استفاده از فناورى اطلاعات در & 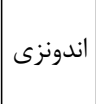 & $1 \cdot r$ & $r \cdot I V$ & ويديا و همكاران \\
\hline 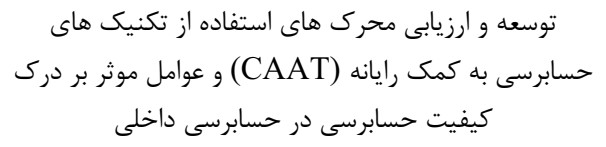 & 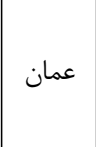 & re. & $r \cdot I V$ & 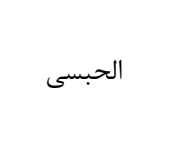 \\
\hline عوامل مرتبط با نخرش حسابرسان براى استفاده داوطلبانه از & 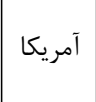 & $11 f$ & $r \cdot I V$ & هاين و كورتيس \\
\hline 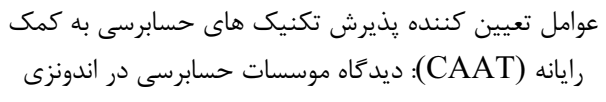 & 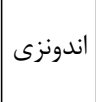 & $|f|$ & $r \cdot I V$ & 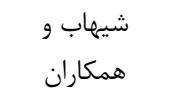 \\
\hline
\end{tabular}


دو فصلنامه حسابدارى ارزشى و رفتارى، سال ششم، شماره يازدهم، بهار و تابستان ++ع|

\begin{tabular}{|c|c|c|c|c|}
\hline تأثير مدل يذيرش فناورى (TAM) بر استفاده حسابرسان از & |ندونزى | & Vr & $r \cdot I V$ & 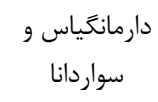 \\
\hline تأثير ادراك فردى از نرم افزار حسابرسى اتوماسيون توسط & فرانسه & $\Delta \Delta$ & $r . I V$ & يغيزو و جافيك \\
\hline قصد استفاده از سيستم حسابرسى الكترونيكى: يرونده اى از & |ندونزى | & $1 \wedge \Delta$ & $r \cdot I V$ & بينهم و همكاران \\
\hline بررسى نكرش حسابرس در استفاده از فن آورى اطلاعات در & اندونزى & $1 \cdot r$ & $r \cdot I V$ & كوسامادئو و \\
\hline تجزيه و تحليل عوامل موثر بر قصد استفاده از نرم افزار & |ندونزى | & 110 & $r \cdot I V$ & حاساين \\
\hline مطالعه ميزان پذيرش و تأثير نرم افزار اتوماسيون حسابرسى حسابرسان مالى حسان & آمريكا & $1 \cdot r$ & $r \cdot 11$ & سفيك و مغَيزا \\
\hline درى كاربرد و ارزش تجزيه و تحليل حسابرسى براى دابى دانى & آمريكا & $r \cdot q$ & $r \cdot 11$ & لى و همكاران \\
\hline حسابرسى مالى جمزيه و تحليل حسوى اندونزى در دفتر الكترونيكى در هيئت إى شمال & |ندونزى | & 9 . & $r .19$ & خوليس و خوايوى \\
\hline 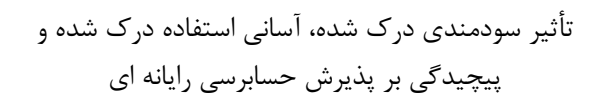 & |ندونزى | اندي & 10. & $r \cdot 19$ & فمبريانتو و \\
\hline تجزيه و تحليل عوامل موثر بر استفاده از فناورى اطلاعات & اندونزى & 1.9 & $r .19$ & سارى و رحمان \\
\hline 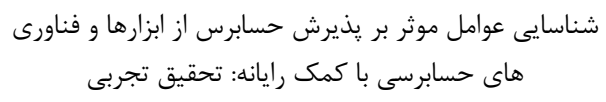 & تركيه & $\Lambda \Delta$ & $r .19$ & دو كاناى \\
\hline فنعيين اهداف رفتارى نسبت به رفتار حسابرس در استفاده از & اندونزى & $1 \cdot V$ & $r .19$ & بمبنَ و ويديا \\
\hline 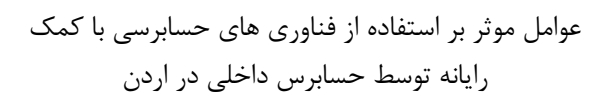 & اردن & $1 \cdot \Delta$ & $r .19$ & آل حمكاران \\
\hline
\end{tabular}




\begin{tabular}{|c|c|c|c|c|}
\hline 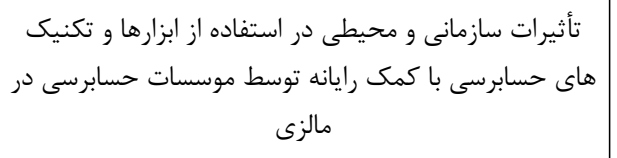 & مالزى & 111 & $r \cdot 19$ & سيئو و همكاران \\
\hline اتخاذ فناورى اطلاعات در موسسات حسابدارى عمومى & | اندونزى | & $1 \cdots$ & $r \cdot 19$ & ويدورى و \\
\hline 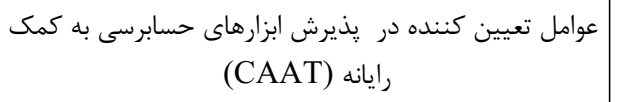 & يرتغال & $1 \ldots$ & $r \cdot 19$ & 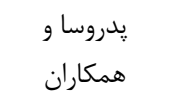 \\
\hline 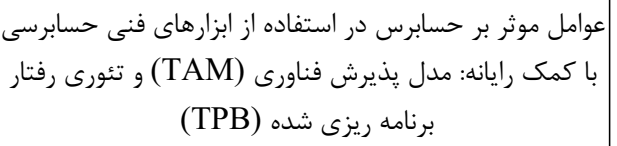 & 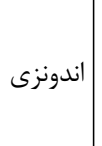 & 1.9 & $r \cdot 19$ & سارى \\
\hline 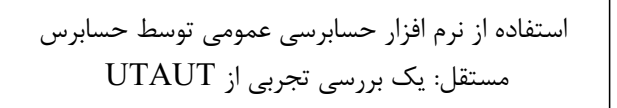 & | اندونزى & 148 & $r \cdot 19$ & 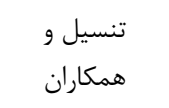 \\
\hline |عوامل موثر در يذيرش تكنيك هاى حسابرسى به كمك رايانه & يمن & TIT & $r \cdot r$. & خليل و اولفا \\
\hline 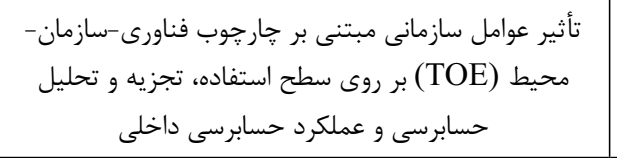 & | سنًَايور & TQT & $r \cdot r$. & 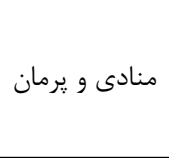 \\
\hline 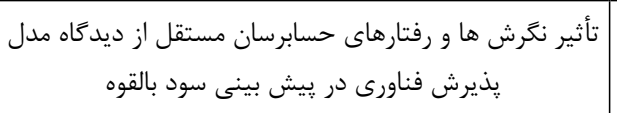 & تركيه & $1 \cdot 1$ & $r \cdot r$. & 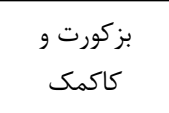 \\
\hline نكرش حسابرس به ديجيتالى شدن در حسابرسى & 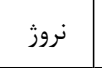 & IVF & $r \cdot r$. & هالاند \\
\hline مديريت انقلاب فناورى: هُونه شركاى حسابرسى تغيير را & آمريكا & $\uparrow \wedge$ & $r \cdot r \cdot$ & ويت و همكاران \\
\hline 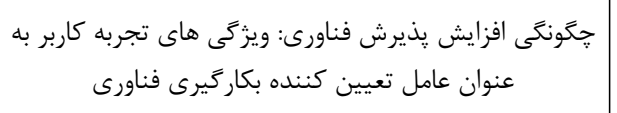 & آلمان & rAl & $r \cdot r \cdot$ & 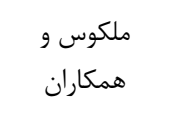 \\
\hline خبر كان مشاركت كننده در اجراى نرم افزار حسابرسى (GAS) در موسسات حسابرسى در مالزى & مالزى & 99 & $r \cdot r \cdot$ & 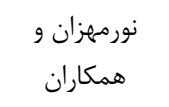 \\
\hline مدل پذيرش محاسبات ابرى در حرفه حسابرسى & 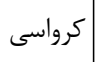 & 111 & $r \cdot r$. & 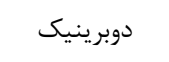 \\
\hline تعيين اهداف حسابرسان براى استفاده از فناورى: شواهدى از & ايتاليا & rVq & $r \cdot r$. & فرى و همكاران \\
\hline
\end{tabular}


دو فصلنامه حسابدارى ارزشى و رفتارى، سال ششم، شماره يازدهم، بهار و تابستان ++ع|

$r+$

\begin{tabular}{|c|c|c|c|c|}
\hline موانع استفاده از فناورى اطلاعات: مطالعه موردى سازمان & اندونزى & 110 & $r \cdot r$. & 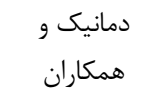 \\
\hline تعديل نقش تعهد مديريت عالى در استفاده از تكنيك هاى & اردن & r & $r \cdot T I$ & داود و همكاران \\
\hline عوامل موثر بر استفاده از نرم افزار حسابرسى عمومى در انيند حسابرسى در اندونزى & اندونزى & $V F$ & $r \cdot T_{1}$ & كارتيكاسرى \\
\hline
\end{tabular}

اكثر مطالعات بكارگرفته شده در هشت سال كذشته ( (VI/) انجام شده (شكل \&) و به طور

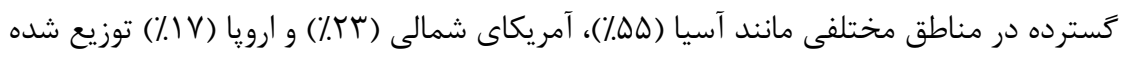

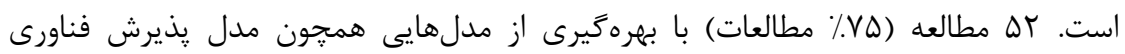

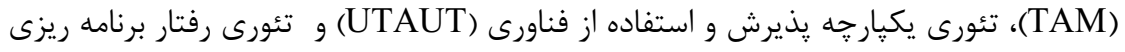

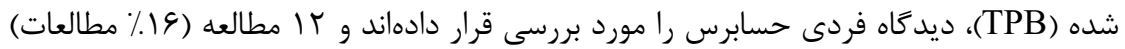

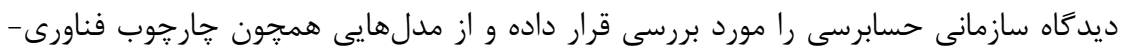

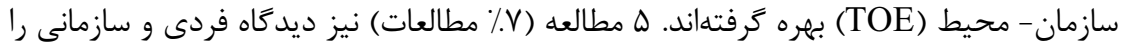

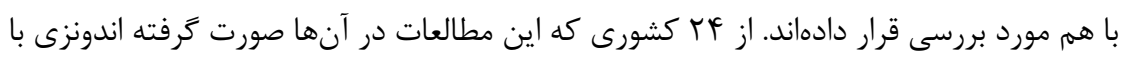
انجام 19 مطالعه، فراوانى بيشترين مطالعات را به خود اختصاص دور دهاص داده است.

\section{شكل 9. فراوانى ساليانه 99 مطالعه بكار كرفته شده در فراتحليل طى 11 سال كذشته}

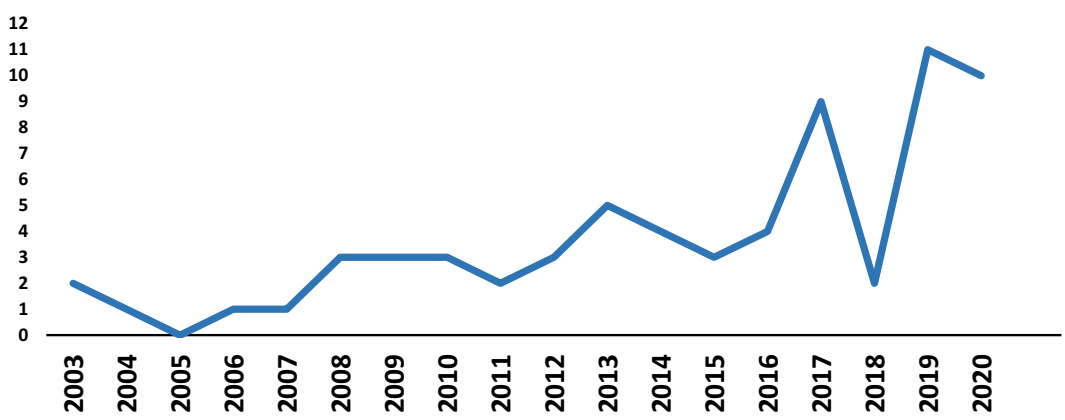

منبع: يافته هاى يزوهش 
دكتر تحريرى و افساى، فراتحليل عوامل موثر بر رفتار حسابر سان جهت يذيرش فناورى اطلاعات

شكل V. طبقه بندى كشورهاى مبدأ و9 مطالعه بكاركرفته شده در فراتحليل

$\begin{array}{llllllllllllllllllll}19 & 18 & 17 & 16 & 15 & 14 & 13 & 12 & 11 & 10 & 9 & 8 & 7 & 6 & 5 & 4 & 3 & 2 & 1 & 0\end{array}$

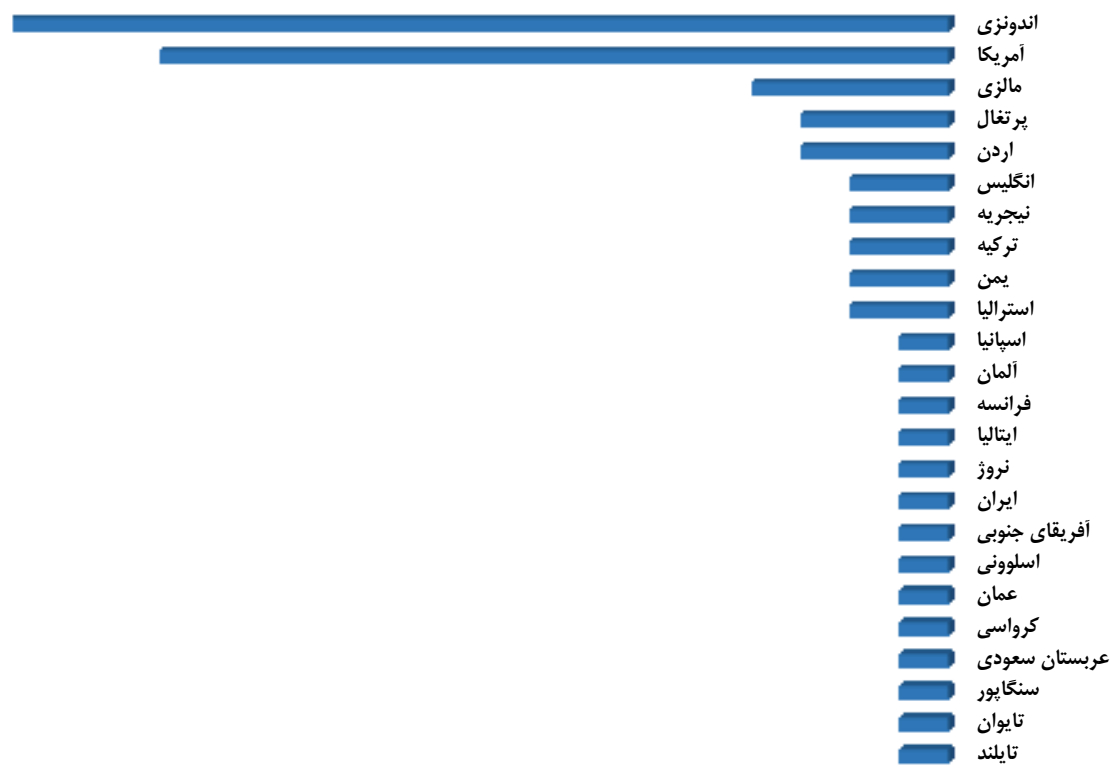

منبع: يافته هاى يزوهش

جمع آورى و تجزيه و تحليل دادهها

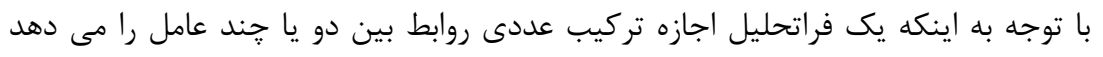

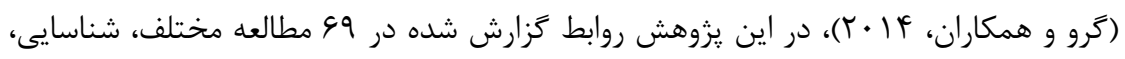

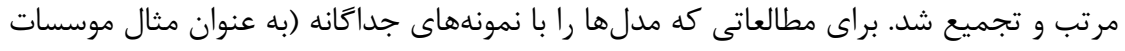

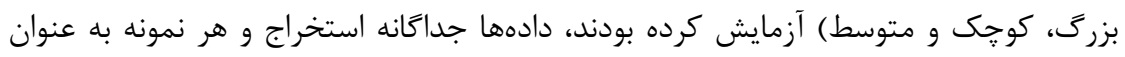

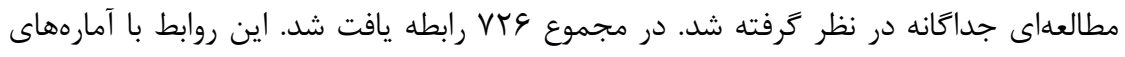

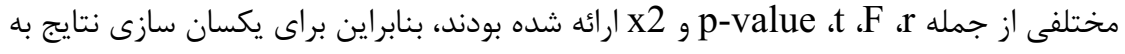

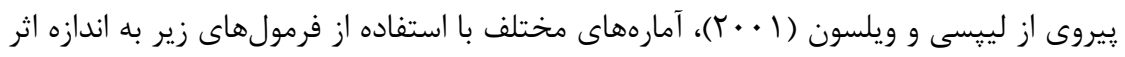

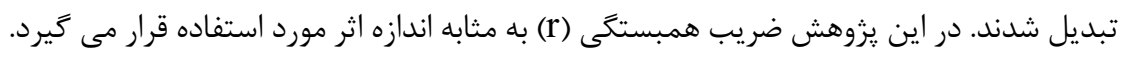

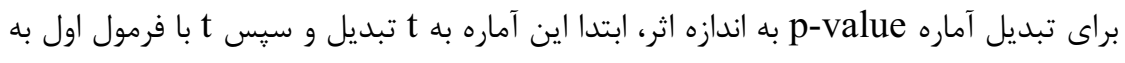

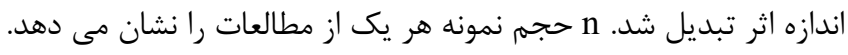


دو فصلنامه حسابدارى ارزشى و رفتارى، سال ششم، شماره يازدهم، بهار و تابستان +•ع|

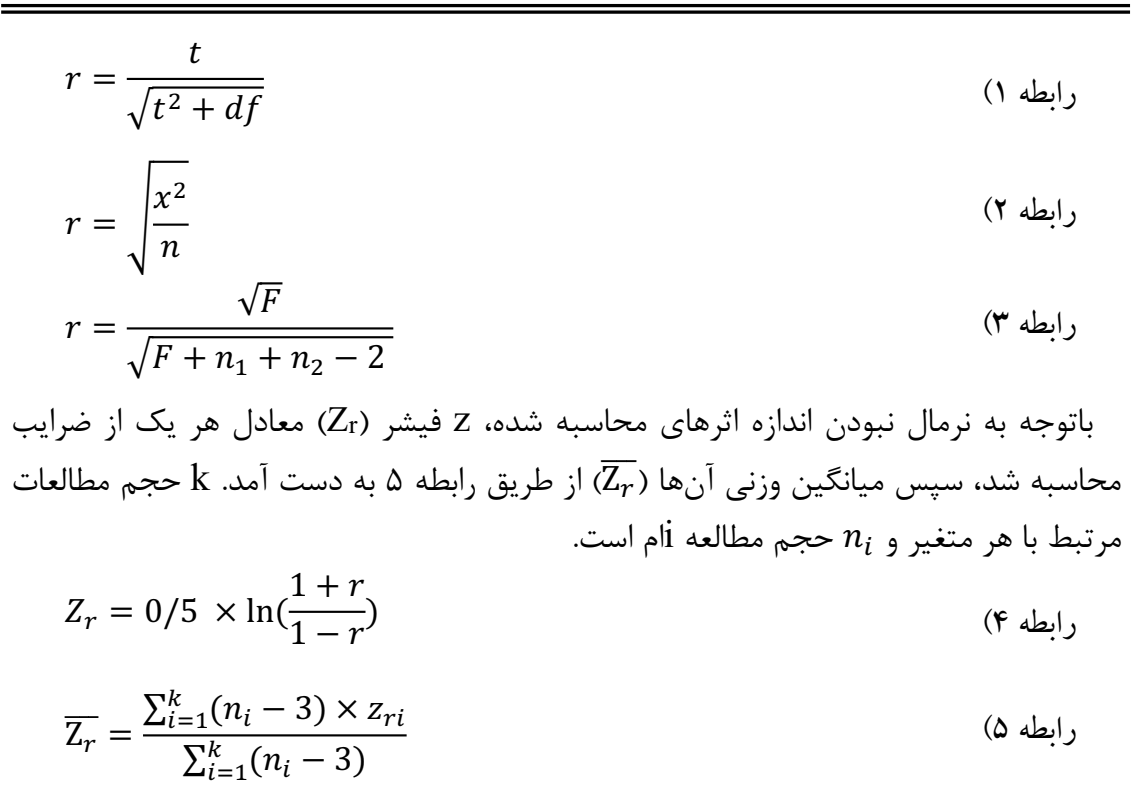

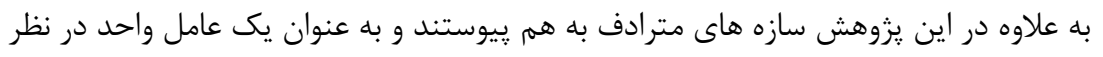

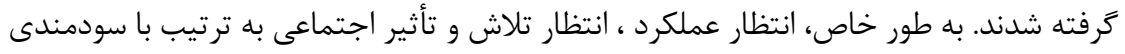

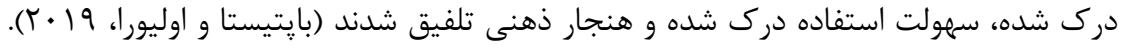

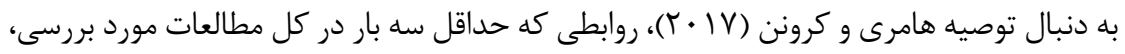

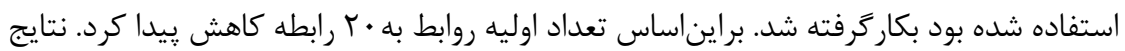
فراتحليل با استفاده از نسخه ب نرم افزار Comprehensive Meta-Analysis بدست آمده است.

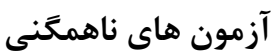

تغييرات اندازه اثر مطالعات، با استفاده از آزمون كوكران (آماره Q (Q) بررسى شد (رابطه و). مقدار

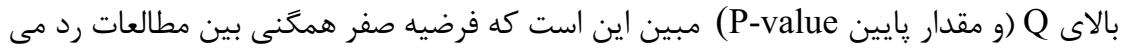

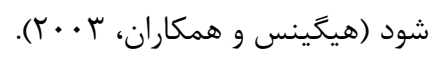

$Q=\sum W_{I}\left(y_{i}-\bar{y}\right)^{2}$

رابطه 9)

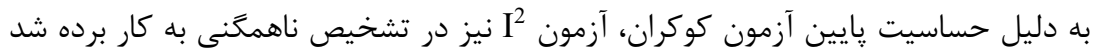

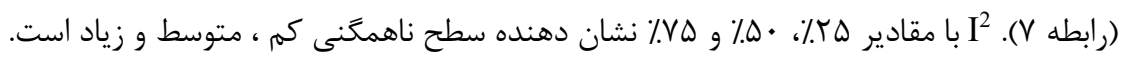

$$
I^{2}=\left(\frac{Q-d f}{Q}\right) \times 100 \quad d f=k-1 \quad \text { (V ) }
$$




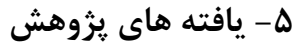

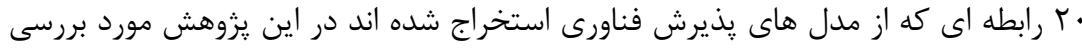

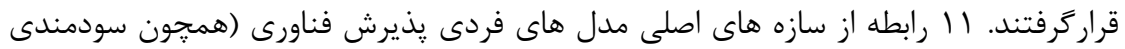

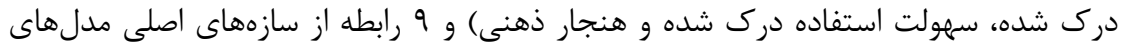

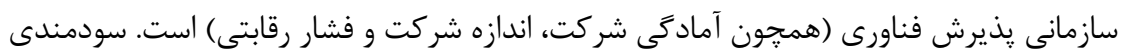

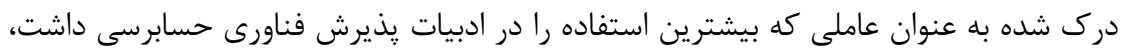

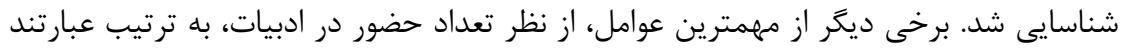

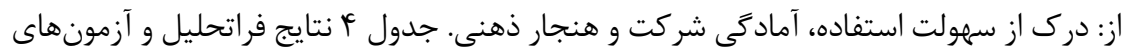

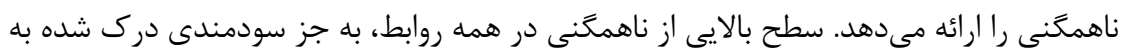

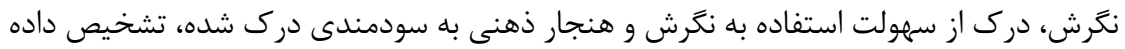

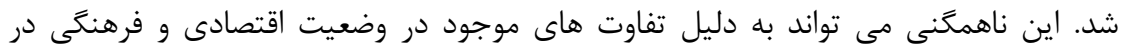

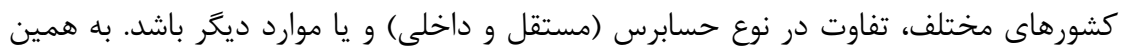

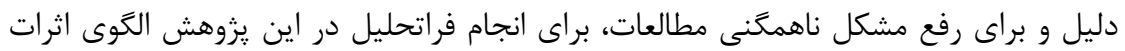

$$
\text { تصادفى بكار گرفته شد (بورنستين، • • • (Y). }
$$

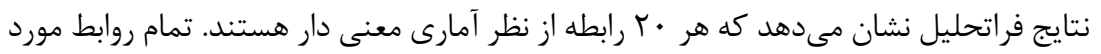

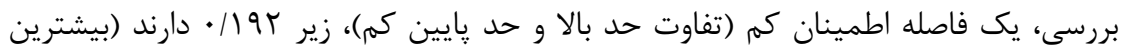

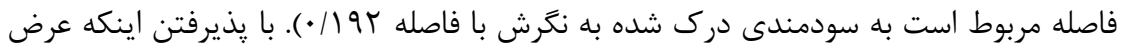

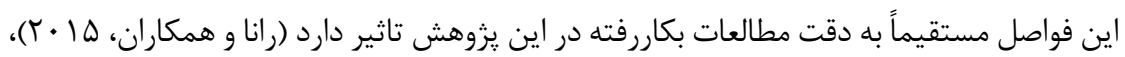

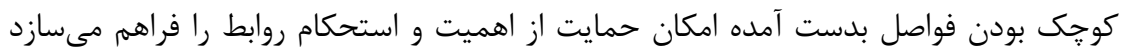

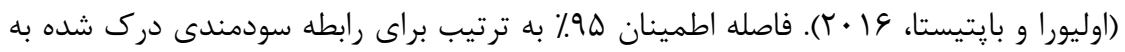

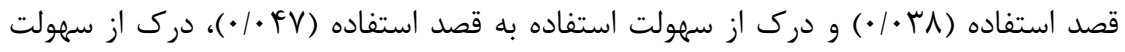

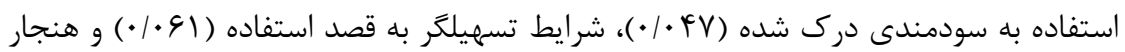

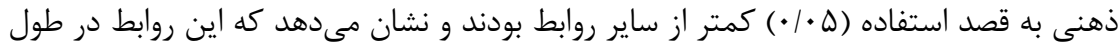
آزمايشات قوى و ساز كار هستند (بايتيستا و اوليورا، 19 • (†).

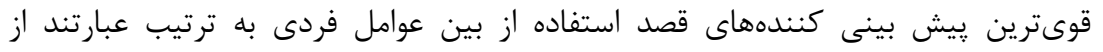

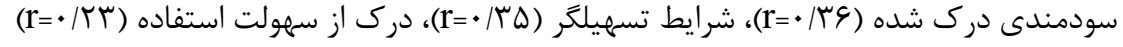

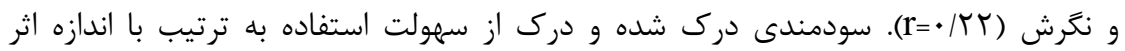

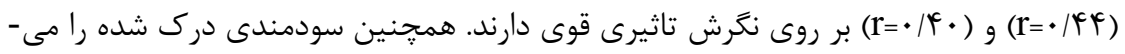

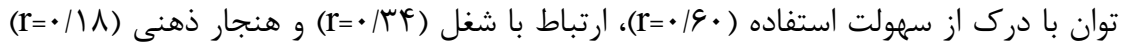

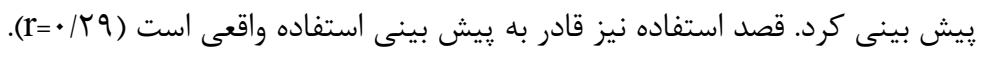


از بين عوامل سازمانى قوىترين بيشبينى كنندههاى قصد استفاده به ترتيب عبارتند از هزينه -

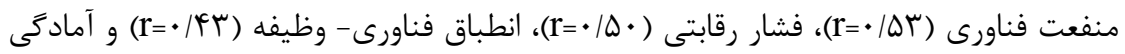

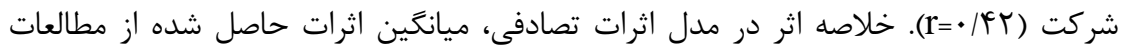

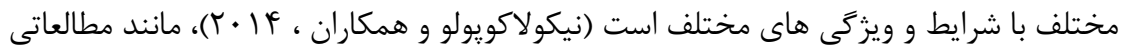

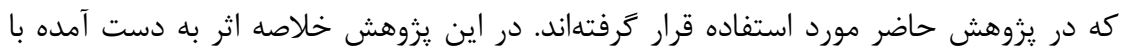

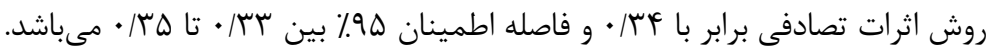

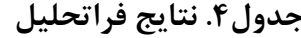

\begin{tabular}{|c|c|c|c|c|c|c|c|}
\hline $\mathrm{I}^{2}$ & 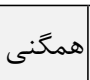 & \multicolumn{2}{|c|}{ فاصله اطمينان } & \multirow{2}{*}{$\frac{\overline{3}}{\frac{0}{12}}$} & \multirow{2}{*}{$\begin{array}{l}\hat{2} \\
3 \\
3 \\
3\end{array}$} & \multirow{2}{*}{$\begin{array}{l}3 \\
\frac{3}{3} \\
3 \\
3 \\
3 \\
\vdots 3\end{array}$} & \\
\hline \multicolumn{2}{|c|}{ (Q- value) } & $\underset{3}{2}$ & $\begin{array}{l}3 \\
3 \\
3 \\
3\end{array}$ & & & & \\
\hline \multicolumn{8}{|c|}{ ديدكاه فردى } \\
\hline$r \cdot / A T$ & $r / \mu V$ & . & $\cdot / \pi 4$ & $\cdot \mid \boldsymbol{F} \mathrm{f}^{* * *}$ & rri & r & سودمندى درك شده † نغرش \\
\hline$V V / F \Delta$ & $r r q / 4$ & $\cdot / \pi \wedge$ & $\cdot / \pi r$ & $\cdot / \pi 4^{* * *}$ & $\vee q \cdot v$ & $\Delta \Delta$ & سودمندى درك شده † قصد استفاده \\
\hline$q \Delta / r \Delta$ & r & .194 & $\cdot \mid \Delta \Lambda$ & $\cdot 19 .^{* * *}$ & rart & 11 & درى ازسهولتاستفاده †سودمندىدركشده \\
\hline$V R / I T$ & $11 / 19$ &.$/ 49$ & $\cdot \pi$ & $\cdot / 4 \cdot{ }^{* * *}$ & rir & r & درى از سهولت استفاده † نكرش \\
\hline $9 \cdot / 4 r$ & $11 \% / 9$ & $\cdot / T V$ &.$/ 1 \mathrm{~V}$ & $\cdot / \pi r^{* * * *}$ & $1 \Delta \Delta V$ & it & نغرش † بصد استفاده \\
\hline ^৭/^〉 & $\Lambda \Lambda / A V$ & r & $\cdot / T F$ & $\cdot / q^{* * *}$ & 1949 & $1 \cdot$ & قصد استفاده † استفاده واقعى \\
\hline$\Lambda F / T G$ & r\$9/9 & $\cdot / T \Delta$ & $\cdot / r$ & $\cdot / r^{* * * *}$ & gसtr & fr & درك از سهولت استفاده × قصد استفاده \\
\hline$V Q / 19$ & $r F / 19$ &.$/ T F$ &.$/ 14$ & $\cdot / 1 \Lambda^{* * *}$ & 990 & $v$ & هنجار ذهنى † سودمندى درى شده \\
\hline$\Lambda \cdot / r \Delta$ & $\mid F V / 4$ & $\cdot / T F$ & $\cdot / 1 \Lambda$ & $\cdot|\pi|^{* * *}$ & Fqवर & $r$. & هنجار ذهنى † قصد استفاده \\
\hline QY/A & \&4/19 & $\cdot / 4$. & $\cdot / 2 \Lambda$ & $\cdot / \pi e^{* * *}$ & V^r & $\Delta$ & ارتباط با شغل † سودمندى درك شده \\
\hline $19 / 94$ & $I F T / T$ & $\cdot / \pi \Lambda$ & . & $\cdot / \pi \omega^{* * *}$ & rtig & $r$ r. & شرايط تسهيلكر † قصد استفاده \\
\hline \multicolumn{8}{|c|}{ ديدگًاه سازمانى } \\
\hline$\Lambda T / r r$ & $9 \cdot 1 \cdot 1$ & $\cdot / \Delta V$ & $\cdot 10 \cdot$ & $\cdot|\Delta|^{* * *}$ & $191 \mathrm{~T}$ & IV & هزينه - منفعت فناورى † قصد استفاده \\
\hline $18 / 91$ & $11 \% / 9$ &.$/ 1 \mathrm{~V}$ & .1 .9 & $\cdot / 1 r^{* * * *}$ & TMFT & 19 & ريسك فناورى † قصد استفاده \\
\hline$\Lambda \Lambda / 11$ & $109 / 1$ &.$/ 48$ & $\cdot / 4$. & $\cdot \mid \mathbb{A r}^{* * * *}$ & 41.9 & $r \cdot$ & انطباق فناورى-وظيفه ٪ قصد استفاده \\
\hline$\Lambda \cdot / \Lambda V$ & $\Delta V / \Delta \mid$ & .119 & $\cdot / \cdot 1$ & $\cdot / 1 f^{* * *}$ & IrTa & ir & اندازه شركت † قصد استفاده \\
\hline s\&/T. & $\Lambda \uparrow / \Lambda$. & $\cdot / 4 F$ & $\cdot / 49$ & $\cdot / \& r^{* * *}$ & 4.99 & r & آمادكى شركت † قصد استفاده \\
\hline $9 \leftrightarrow / \uparrow \wedge$ & $r q \cdot 11$ & . Mt & $\cdot / r V$ & $\cdot / \Upsilon^{* * *}$ & rasv & 11 & حمايت مديريت ارشد ٪ قصد استفاده \\
\hline$q \uparrow / v q$ & $r \& q / \Lambda$ & $\cdot / \mu$ & $\cdot / 4 t$ & $\cdot / r 4^{* * *}$ & 1919 & If & پِيجيدگى سيستم فناورى اطلاعات مشترى † قصد استفاده \\
\hline $9 \$ / V 1$ & $I M T / F$ & $\cdot / D F$ & $\cdot / 4 V$ & $\cdot 10 \cdot^{* * *}$ & $1 \Lambda T \Delta$ & $\Lambda$ & فشار رقابتى † قصد استفاده \\
\hline \multirow[t]{2}{*}{$\Lambda \Delta / \cdot r$} & $\pi \cdot / 4$ & 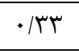 & $\cdot / \pi \Delta$ & $\cdot / \Upsilon^{* * *}$ & | & 19 & يشتيبانى نهادهاى حرفه اى ٪ قصد استفاده \\
\hline & & $\cdot / \mathrm{s} a$ & r & $\cdot / \mu f^{* * * *}$ & & & خلاصه اثرات (تصادفى) \\
\hline
\end{tabular}




\section{تجزيه و تحليل زيركروه}

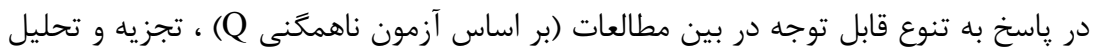

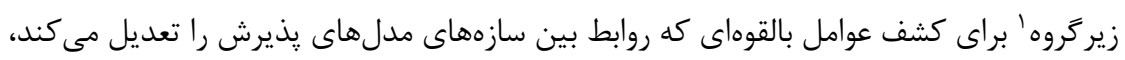

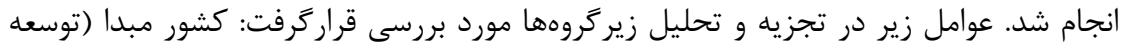

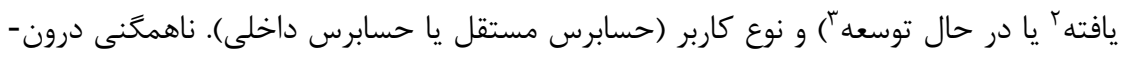

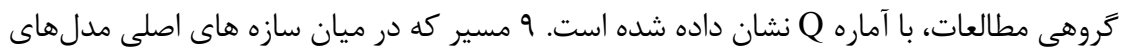

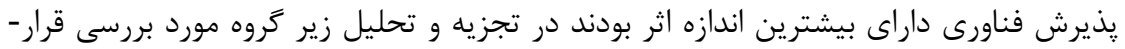

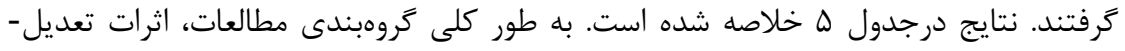

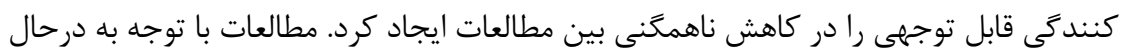

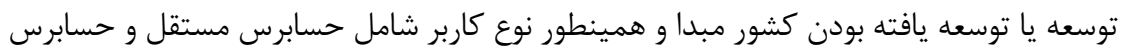
داخلى تروه بندى شدند.

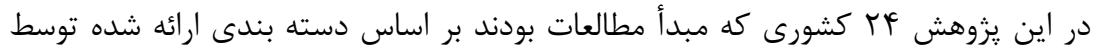

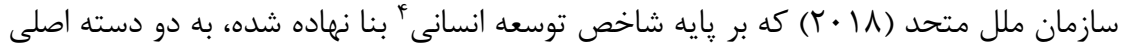

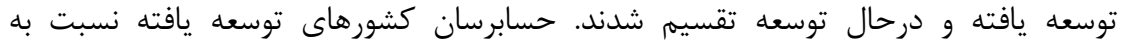

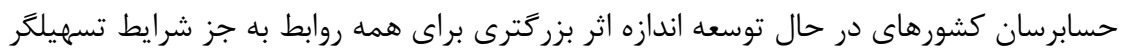

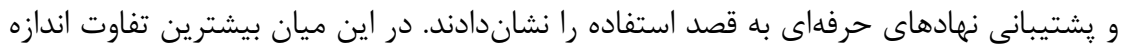

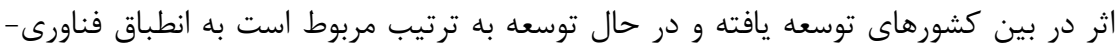

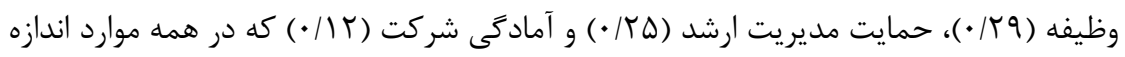

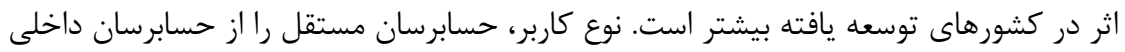

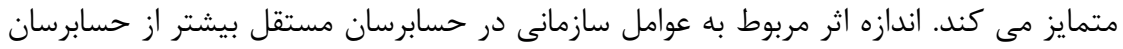

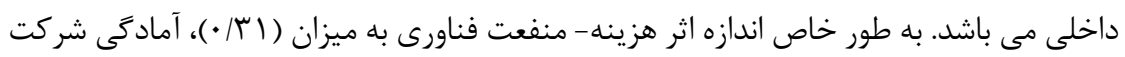

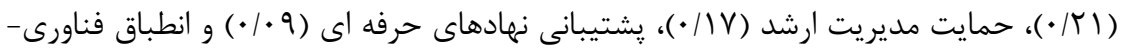

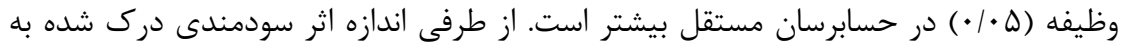

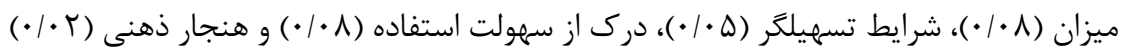

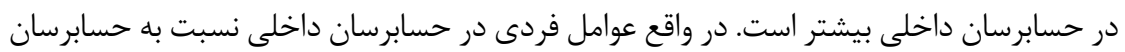

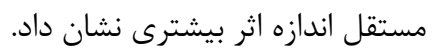

${ }^{1}$ subgroup analysis

2 developed country

${ }^{3}$ developing country

${ }^{4}$ Human Development Index 


\begin{tabular}{|c|c|c|c|c|}
\hline \multicolumn{5}{|c|}{ جدوله. نتايج تجزيه و تحليل زير گروه } \\
\hline \multicolumn{2}{|c|}{ نوع حسابرس } & \multicolumn{2}{|c|}{ نوع كشور } & \\
\hline \multirow[t]{2}{*}{ ل } & مستقل & توسعه يافته & در حال توسعه & \\
\hline & & & \multicolumn{2}{|c|}{ سودمندى درى شده † قصد استفاده } \\
\hline 9 & $4 q$ & 19 & re & تعداد مطالعه \\
\hline \multirow{3}{*}{ 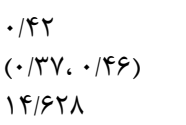 } & 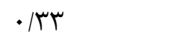 & $\cdot / 49$ & 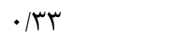 & اندازهاثر \\
\hline & $(\cdot / \pi 1, \cdot / \pi \Delta)$ & $\left(\cdot / \pi \varepsilon_{،} \cdot / 41\right)$ & $(\cdot / \pi 1, \cdot / \pi 4)$ & (حديايين، بالا) \\
\hline & $\mid \Lambda \Delta / \cdot \nvdash \Lambda$ & VN/VEF & $10 F / 9 \Lambda$ & $\mathrm{Q}$ \\
\hline & & & \multicolumn{2}{|c|}{ درى از سهولت استفاده ٪ قصد استفاده } \\
\hline V & 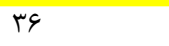 & 10 & rA & تعداد مطالعه \\
\hline \multirow{2}{*}{$\begin{array}{l}\cdot / r q \\
\left(\cdot / r F_{6} \cdot / \mu F\right)\end{array}$} & $\cdot / 41$ & 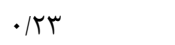 & $\cdot \pi r$ & اندازهاثر \\
\hline & $\left(\cdot / 1 \Lambda_{6} \cdot / R F\right)$ & $(\cdot / T \cdot, \cdot / R V)$ & $(\cdot / 19 ، \cdot / r \Delta)$ & (حديايين، بالا) \\
\hline \multirow[t]{2}{*}{$\Delta F / T T V$} & $r \cdot 9 / \mathrm{r} / \mathrm{V}$ & ITK/GDT & IFN/AFD & $\mathrm{Q}$ \\
\hline & & & \multicolumn{2}{|c|}{ هنجار ذهنى † ق قصد استفاده } \\
\hline \multirow{5}{*}{$\begin{array}{l}D \\
\cdot / r r \\
(\cdot / / V ، \cdot / T q) \\
r F / 9 V F\end{array}$} & TD & it & 11 & تعداد مطالعه \\
\hline & $\cdot|r|$ & $\cdot / 4$ & \multirow{3}{*}{$\begin{array}{l}\cdot / T T \\
(\cdot / / \Lambda \sigma \cdot / T \Delta) \\
\text { NF/AVD }\end{array}$} & اندازهاثر \\
\hline & $\left(\cdot / 1 \Lambda_{6} \cdot / T F\right)$ & $\left(\cdot / I V_{6} \cdot / T F\right)$ & & (حديايين، بالا) \\
\hline & IIT/ATA & gr/.人r & & $\mathrm{Q}$ \\
\hline & & & \multicolumn{2}{|c|}{ شرايط تسهيلكر > قصد استفاده } \\
\hline \multirow{5}{*}{$\begin{array}{l}f \\
. / r q \\
(\cdot / r r \cdot \cdot / 4 \Delta) \\
r q / q \cdot \Delta\end{array}$} & 19 & V & Ir & تعداد مطالعه \\
\hline & $\cdot / \mu r$ & $\cdot / \mu r$ & \multirow{3}{*}{ 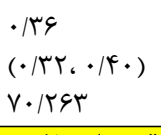 } & اندازهاثر \\
\hline & $(\cdot / r \cdot ، \cdot / r V)$ & $(\cdot / r q ، \cdot / r q)$ & & (حديايين، بالا) \\
\hline & $1 \cdot 1 / 1 \cdot r$ & $V T / T \Delta R$ & & $\mathrm{Q}$ \\
\hline & & & \multicolumn{2}{|c|}{ هزينه - منفعت فناورى † قصد استفاده } \\
\hline \multirow{5}{*}{$\cdot / r \Delta$} & 19 & 9 & \multirow{5}{*}{$\begin{array}{l}\Lambda \\
\cdot / \& q \\
\left(\cdot / \& r_{1} \cdot / \Delta \Delta\right) \\
r V / \Delta \Delta \mid\end{array}$} & تعداد مطالعه \\
\hline & $\cdot 109$ & $\cdot / \Delta \Delta$ & & اندازهاثر \\
\hline & $\left(\cdot / \Delta r_{\cdot} \cdot / \varphi_{\cdot}\right)$ & $(\cdot / 01, \cdot 109)$ & & (حديايين، بالا) \\
\hline & $R A / N I t$ & gq/AFt & & $\mathrm{Q}$ \\
\hline & & & & انطباق فناورى - وظيفه × قصد استفاده \\
\hline \multirow{4}{*}{$\begin{array}{c}1 \\
\cdot \pi /\end{array}$} & 19 & \& & & تعداد مطالعه \\
\hline & $\cdot /$ at & $\cdot / \Delta \Delta$ & $\cdot / r \Delta$ & اندازهاثر \\
\hline & $(\cdot / 4 \cdot, \cdot / 4 \varepsilon)$ & $\left(\cdot\left|\Delta r_{6} \cdot\right| \Delta \Lambda\right)$ & $(\cdot / r \cdot, \cdot / r \cdot)$ & (حديايين، بالا) \\
\hline & $19 \cdot 1194$ & r & $\Delta r / 1 \cdot 1$ & $\mathrm{Q}$ \\
\hline & & & تفاده & آمادכى شركت \\
\hline$r$ & $r \Lambda$ & 9 & rt & تعداد مطالعه \\
\hline$\cdot / T F$ & $\cdot / 48$ & $\cdot / 4 \mathrm{~V}$ & $\cdot / \pi \Delta$ & اندازهاثر \\
\hline$(\cdot / \mid V ، \cdot / \mu l)$ & $\left(\cdot / 4 r_{0} \cdot / 4 q\right)$ & $\left(\cdot\left|F F_{6} \cdot\right| \Delta \mid\right)$ & $(\cdot / \pi 1 ، \cdot / r q)$ & (حديايين، بالا) \\
\hline T/FVT & $\Delta F / G \wedge \Delta$ & $r q / q \cdot r$ & FN/AT. & Q \\
\hline & & & صد استفاده & حمايت مديريت \\
\hline$\Delta$ & Ir & 9 & 9 & تعداد مطالعه \\
\hline$\cdot / \pi s$ & $\cdot / 48$ & $\cdot / 49$ & $\cdot / T F$ & اندازهاثر \\
\hline$(\cdot / r \cdot, \cdot / \pi 1)$ & $\left(\cdot / 4 r_{0} \cdot / 4 q\right)$ & $\left(\cdot / 4 \varepsilon_{،} \cdot \mid \Delta r\right)$ & $(\cdot / 19 ، \cdot / 49)$ & (حديايين، بالا) \\
\hline $\mid V / \cdot .9$ & $r 19 / 194$ & $|\& N / G \cdot|^{k}$ & $\varphi \cdot / \pi \omega \cdot$ & Q \\
\hline
\end{tabular}




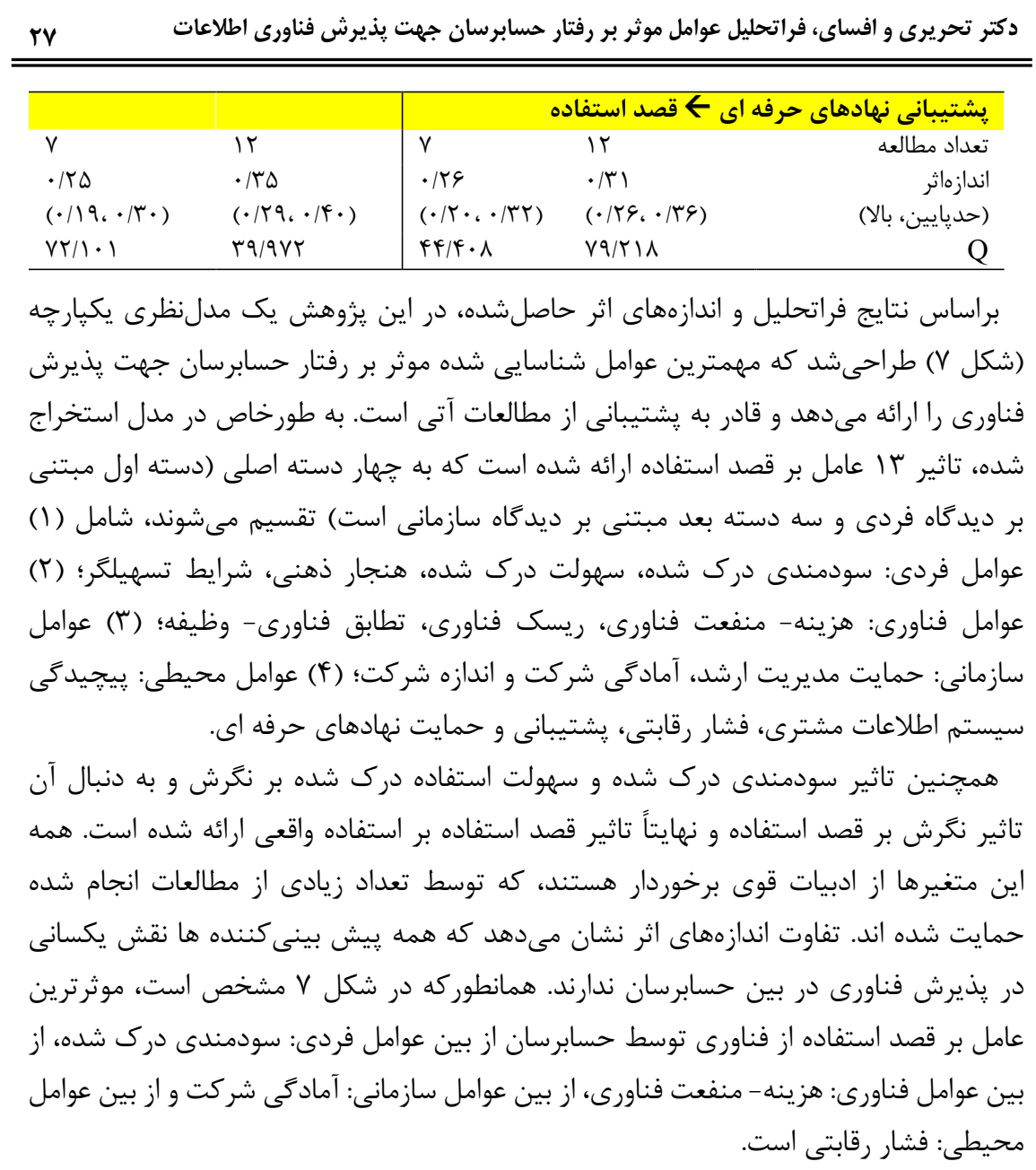


دو فصلنامه حسابدارى ارزشى و رفتارى، سال ششم، شماره يازدهم، بهار و تابستان + +عا1

شكل V. مدل تئوريك مبتنى بر نتايج فراتحليل

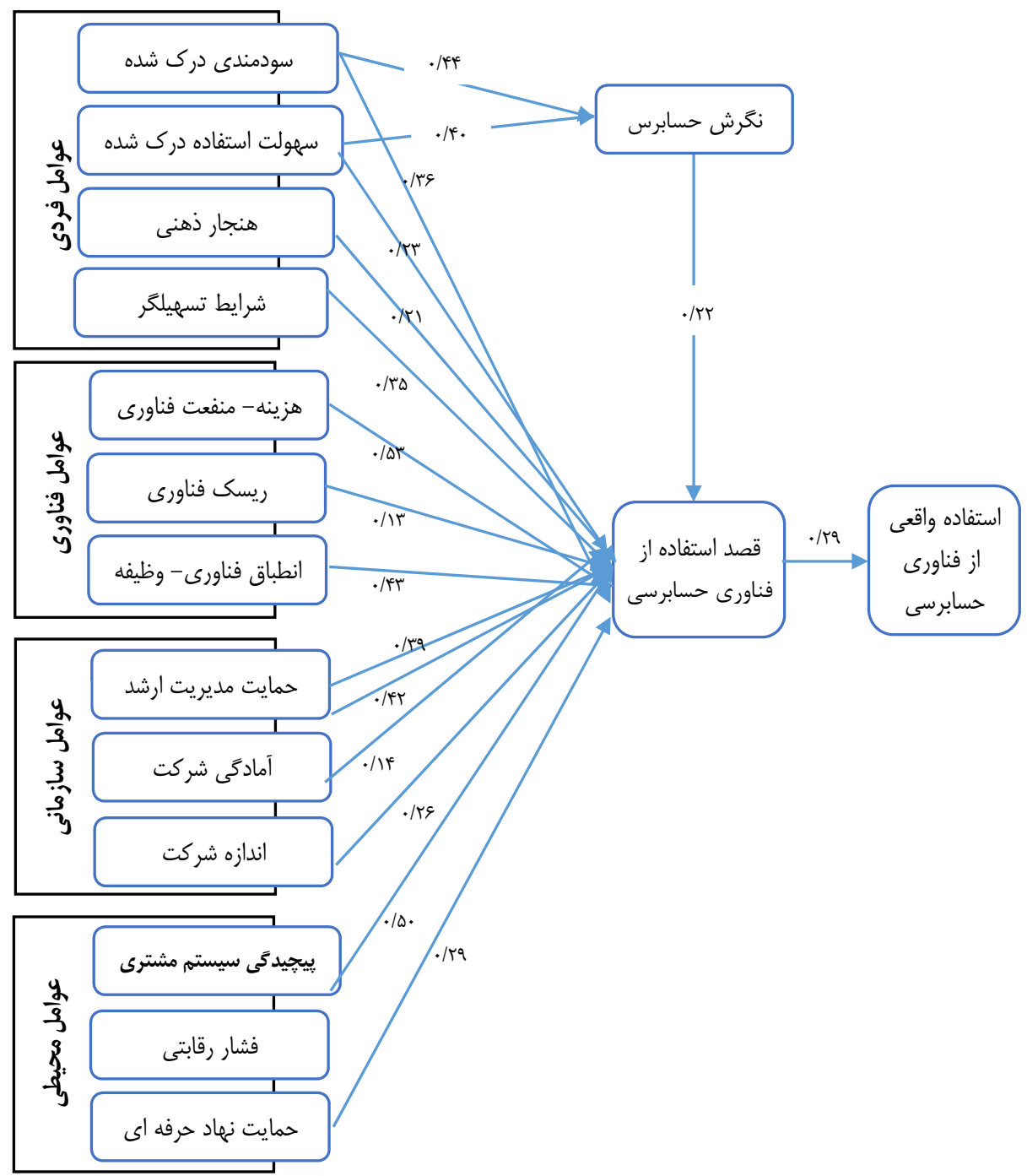

$$
\text { 4- بحث و نتيجه تيرى }
$$

در حالى كه فناورى در فرآيندهاى تجارى نفوذ كرده و دنياى تجارت را متحول ساخته است،

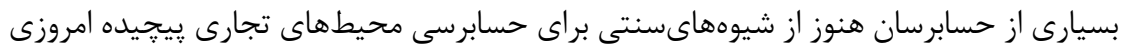

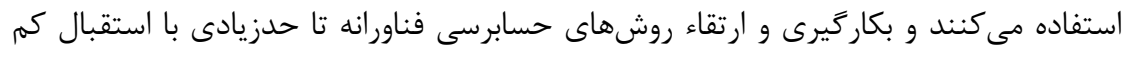


حسابرسان و استفاده كم از اين فناورىها مهار مىشود. هدف از مطالعه حاضر بررسى

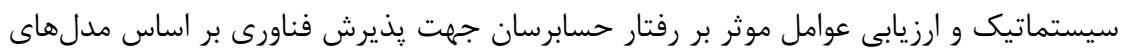

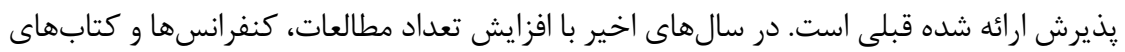
منتشر شده راجع به موضوع يذيرش فناورى در حسابرسى، بررسى دئى ادبيات در اين زمينه

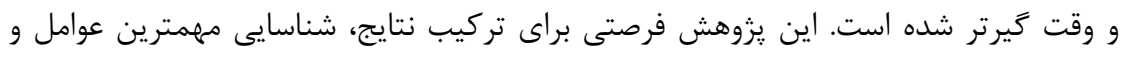

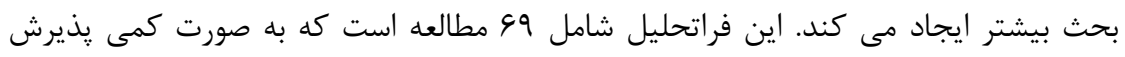

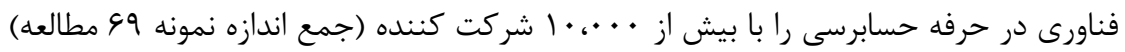

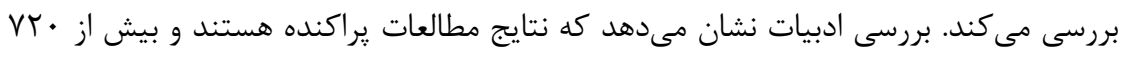

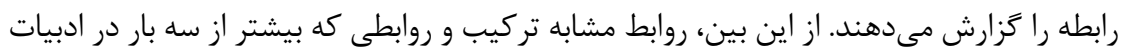

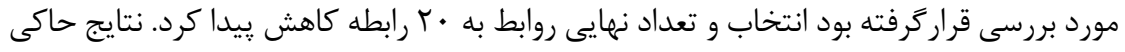

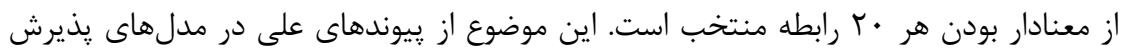

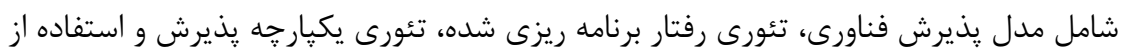

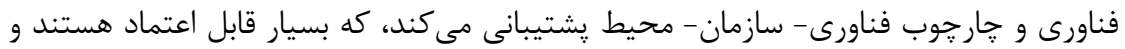

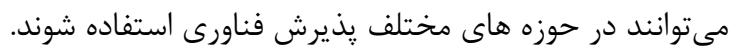

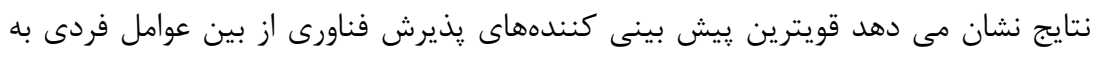

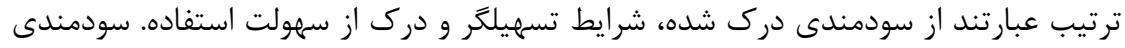

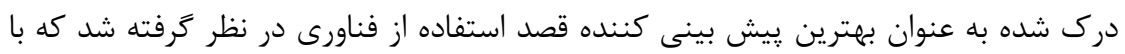

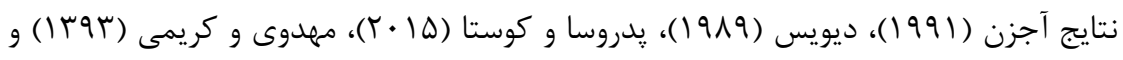

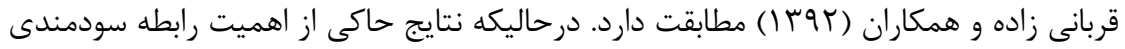

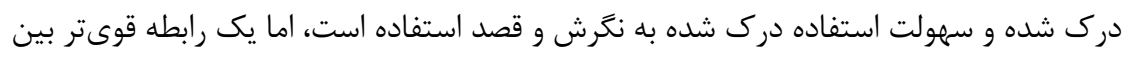

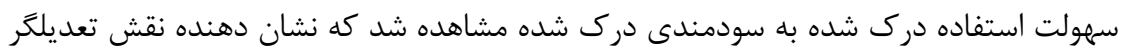

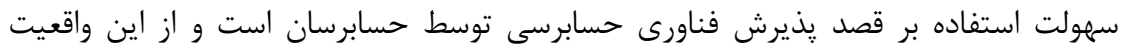

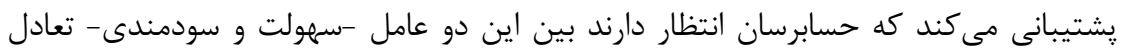

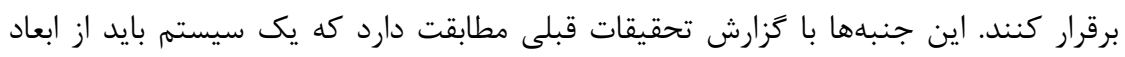

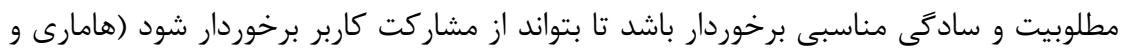

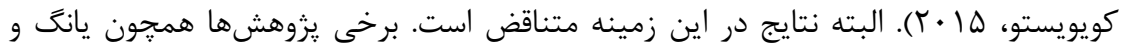

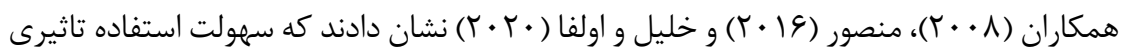

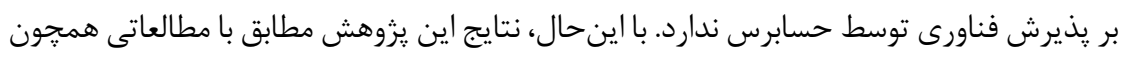

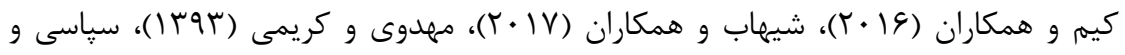

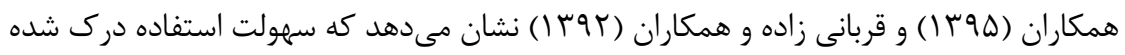


بر يذيرش فناورى توسط حسابرسان به صورت مستقيم و غيرمستقيم تاثير گذار است. منظور از

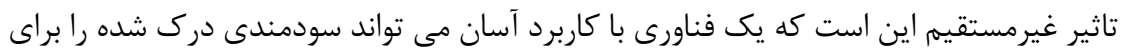
حسابرسان افزايش دهد. علاوه بر اين، سودمندى درك شده و درك از سهولت استفاده تاثير قدرتمندى را بر نكرش

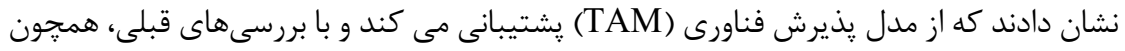

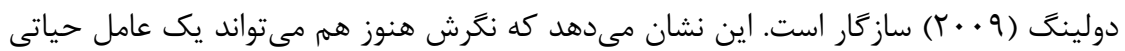
در بذيرش به حساب آيد و موقعيت آن در نظريههاى بذيرش ممكن است مستلزم تجديد نظر

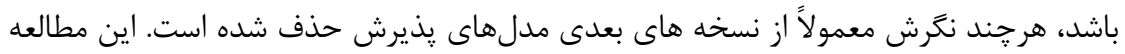

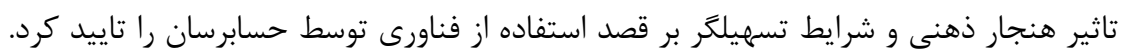

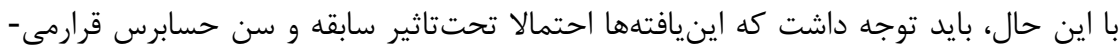

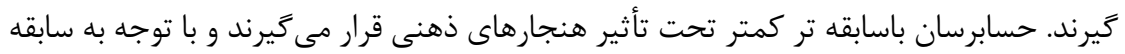
طولانى در انجام حسابرسى سنتى، ذهنى متعصب و ساختار يافته دارند دارند (شايسته شجاعى داري

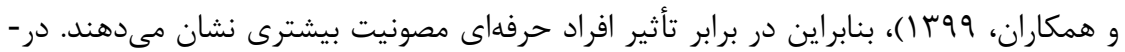

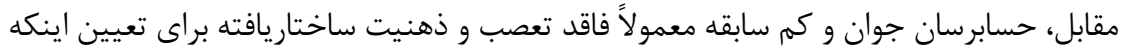

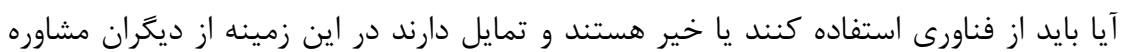

$$
\text { بكيرند (فليسجر، 1999). }
$$

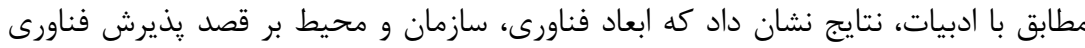

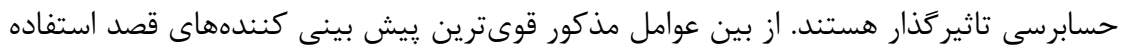

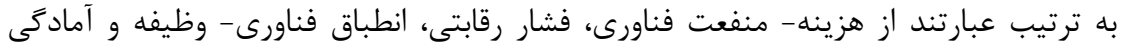

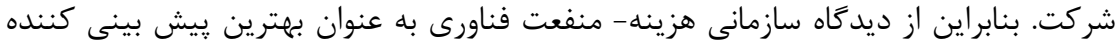

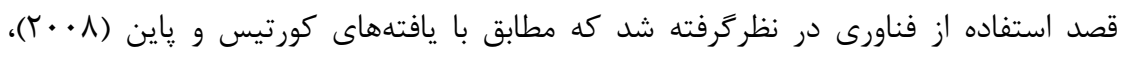

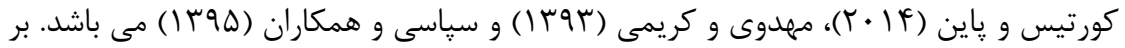

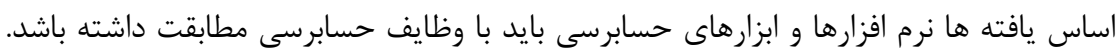

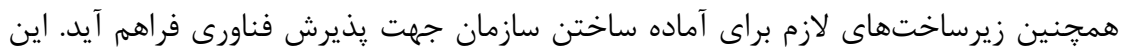

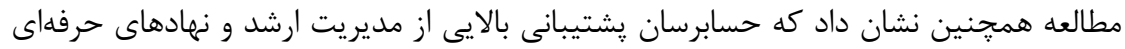

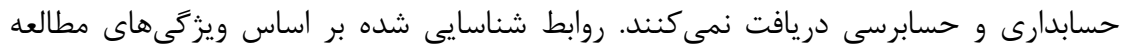

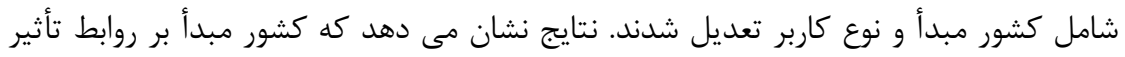
مى كذارد. تاثير شرايط تسهيلكر در كشورهاى درحال توسعه بيشتر از كشور هاى توسعه يافته است.

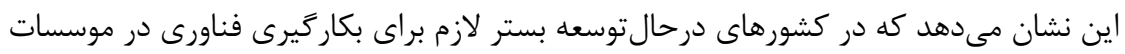

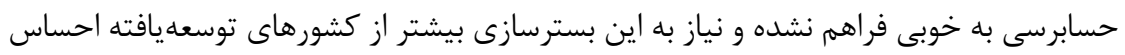


مىشود. بر اساس نتايج، تاثير يشتيبانى نهادهاى حرفهاى در كشورهاى درحالتوسعه بيشتر از

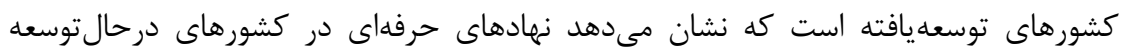

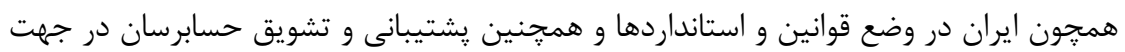

يذيرش فناورى بايد قوىتر عمل كنند تا اين فناورىها در حرفه حسابرسى

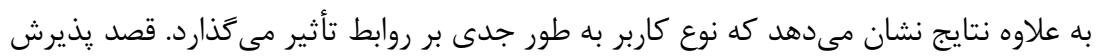

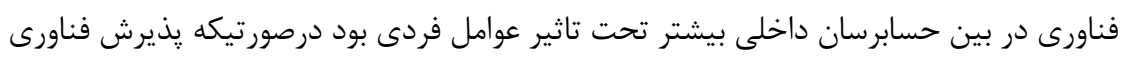

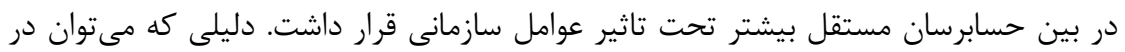

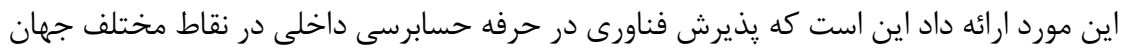

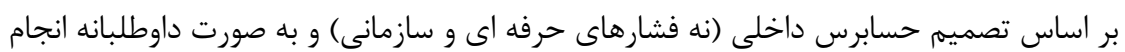
مى شود و عوامل فردى تا حدود زيادى در يذيرش يا عدم يذيرش اين فناورى إنها

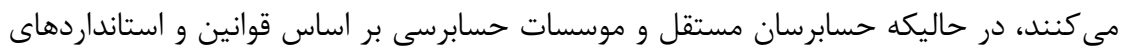

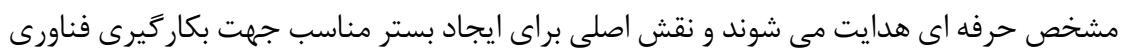
در اين بين بر عهده موسسه حسابرسى و نهادهاى حرفهاى است نه شخص إنص حسابرس.

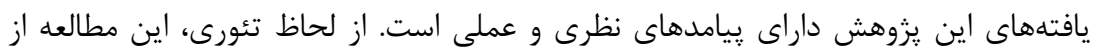

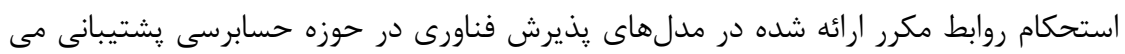

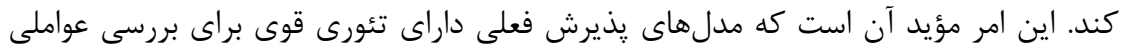

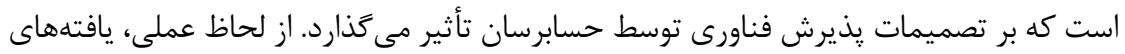

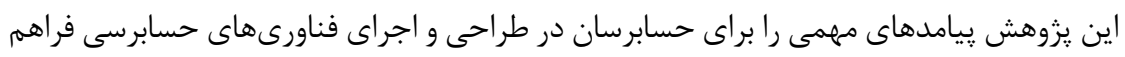

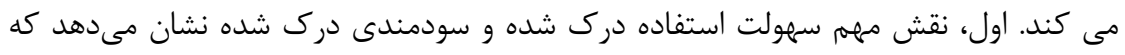

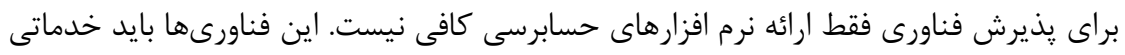

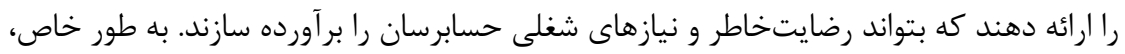

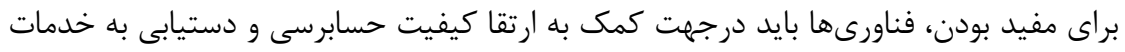

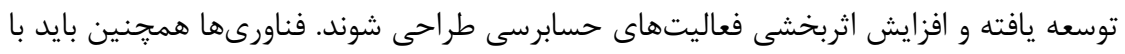

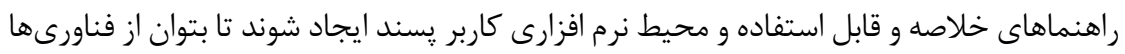

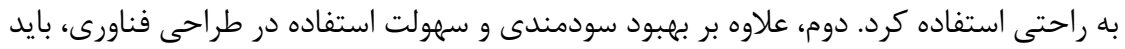

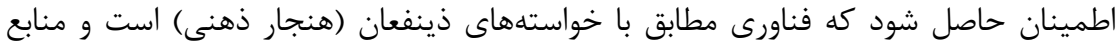

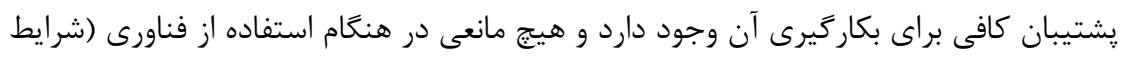

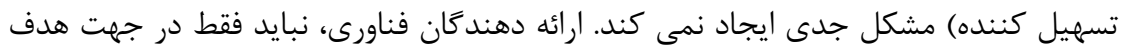
قرار دادن حسابرسان براى يذيرش فناورى تلاش كنند، بلكه با توجه به اهميت هنجارهاى ذهان ذهنى،

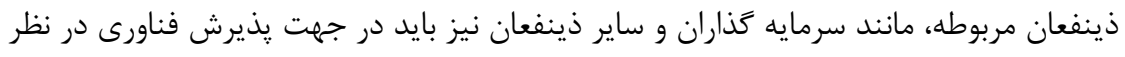


گرفته شوند. انتقال ييام هاى واضح و روشن به كليه ذينفعان مربوطه در مورد اينكه اين فناورى مى تواند در فعاليت هاى اطمينان بخشى و مشاوره مالى فوايدى به همراه داشته باشد، مهرم است.

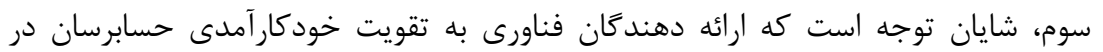
استفاده از فناورى توجه كنند. مجموعه راهنمايىهاى عملى، فيلمهاى آموزشى و كلاسهاى ضمن خدمت درخصوص نحوه استفاده از فناورىها مىتواند راهبردهاى عملى براى دستيابى به

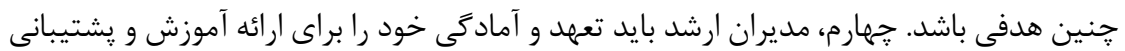

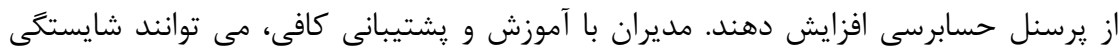
كاركنان را افزايش داده و فناورى حسابرسى را با موفقيت ييادهسازى كنند. ينجمم، نهادهاى

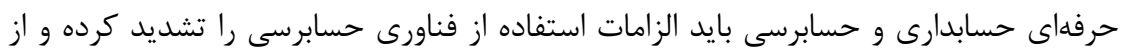

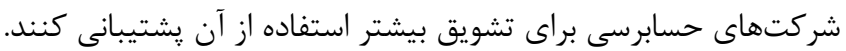

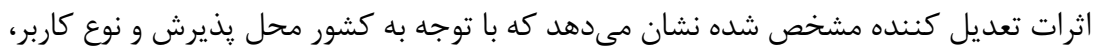
ممكن است به استراترىهاى مختلفى براى طراحى و ريادهسازى فناورى نياز باشد. به عنوان مثال، روند يذيرش فناورى بين حسابرسان داخلى در مقايسه با حسابرسان مستقل ممكن است بـ بسيار متفاوت باشد. بر اساس يافته ها، براى حسابرسان داخلى عوامل فردى شامل سودمندى

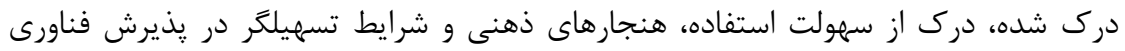
مهمتر است، در حالى كه عوامل فناورانه، عوامل سازمانى و عوامل محيطى بيشتر حسابرسان مستقل را تحت تاثير قرار مىدهد. بنابراين، طراحى و اجراى استراتزىهاى موفقيت آميز براى حسابرسان داخلى ممكن است براى حسابرسان مستقل خوب عمل نكند. اين نشان مي دهد كه طراحى و اجراى استراتزىهاى متناسب با انواع خاص كاربر موردنياز است. علاوهبراين، حسابرسانى كه قصد بكارگيرى فناورىهاى جديد را دارند بايد بدانند كه يذيرش فناورى ممكن است تحت تاثير وضعيت اقتصادى و فرهنكَى يك كشور، متفاوت باشد. به عنوان مثال، شرايط تسهيلگر و ودان يشتيبانى نهادهاى حرفهاى در كشورهاى درحال توسعه همجون ايران، نسبت به كشور هاى توسعه-

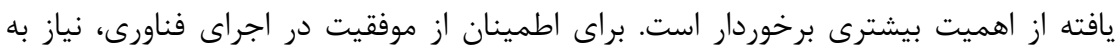
شناسايى مهمترين عوامل تعيين كننده يذيرش حسابرسان در جوامع محلى خاص است.

محدوديتها و ييشنهادها

اين مطالعه با محدوديت هايى همراه بود كه بايد مورد توجه قرار گيرد. اول، همه مطالعات

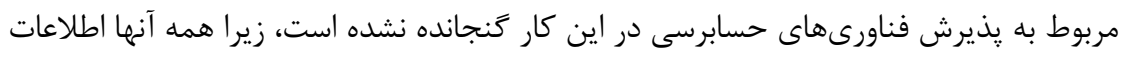

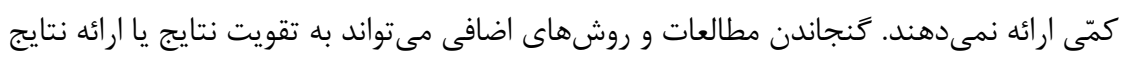
متفاوت منجر شود. دوم، در تجزيهو تحليل زير گروه برخى ناهمگَىهاى متوسط به بالا وجود

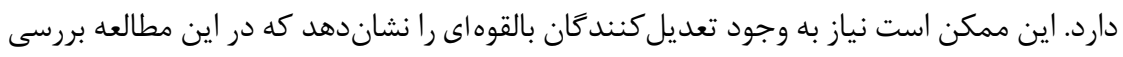


نشده است. با اين حال، محدوديت در تعداد صفحات اكثر مطالعات مانع از ارزيابى نقش تعداد

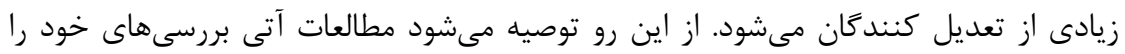

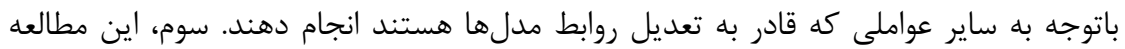

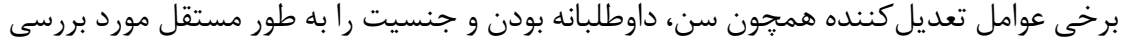

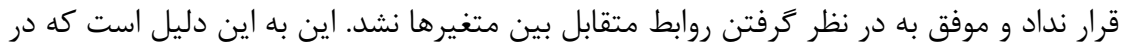

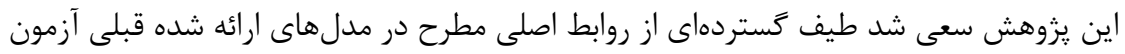

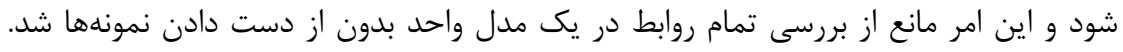

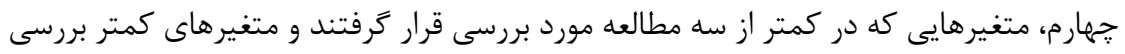

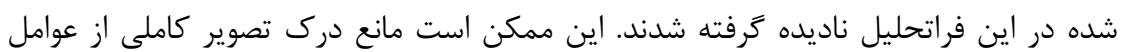

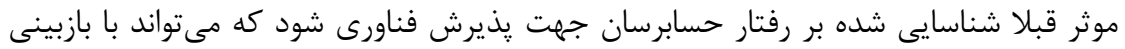

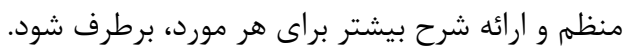

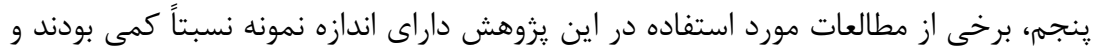

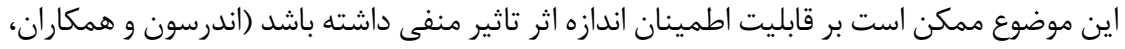

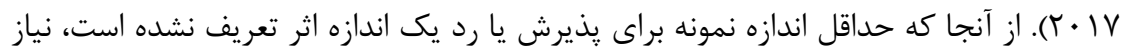

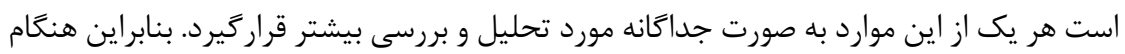

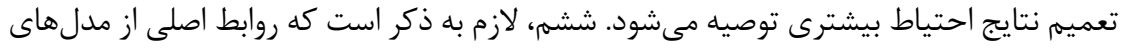

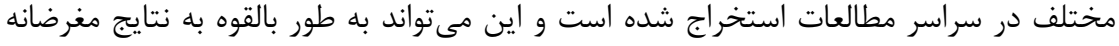

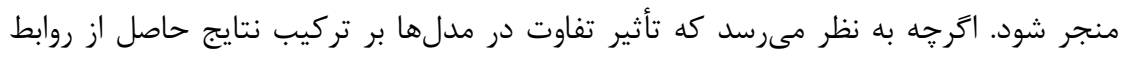
مشخص نيست يا مىتواند كم اهميت باشد، اما در تفسير نتايج فراتحليل بايد احتياط شود.

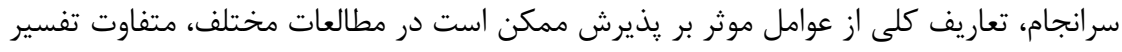

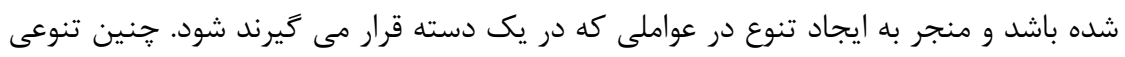

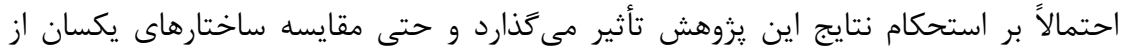

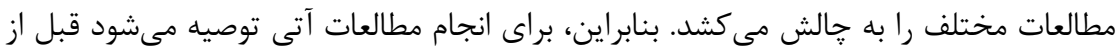

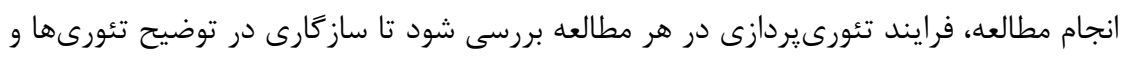

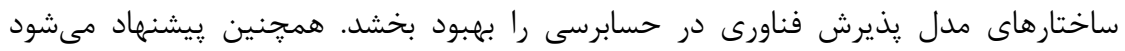

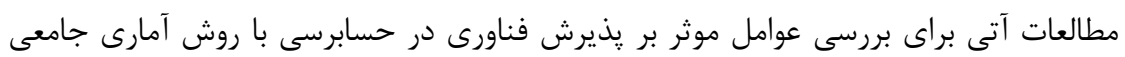

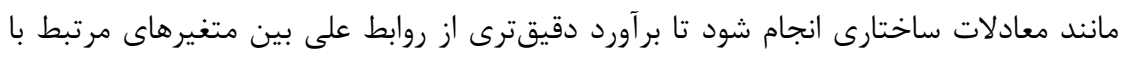
يذيرش فناورى بدست آيد. 


$$
\begin{aligned}
& \text { دو فصلناهه حسابدارى ارزشى و رفتارى، سال ششم، شماره يازدهم، بهار و تابستان +•ع| }
\end{aligned}
$$

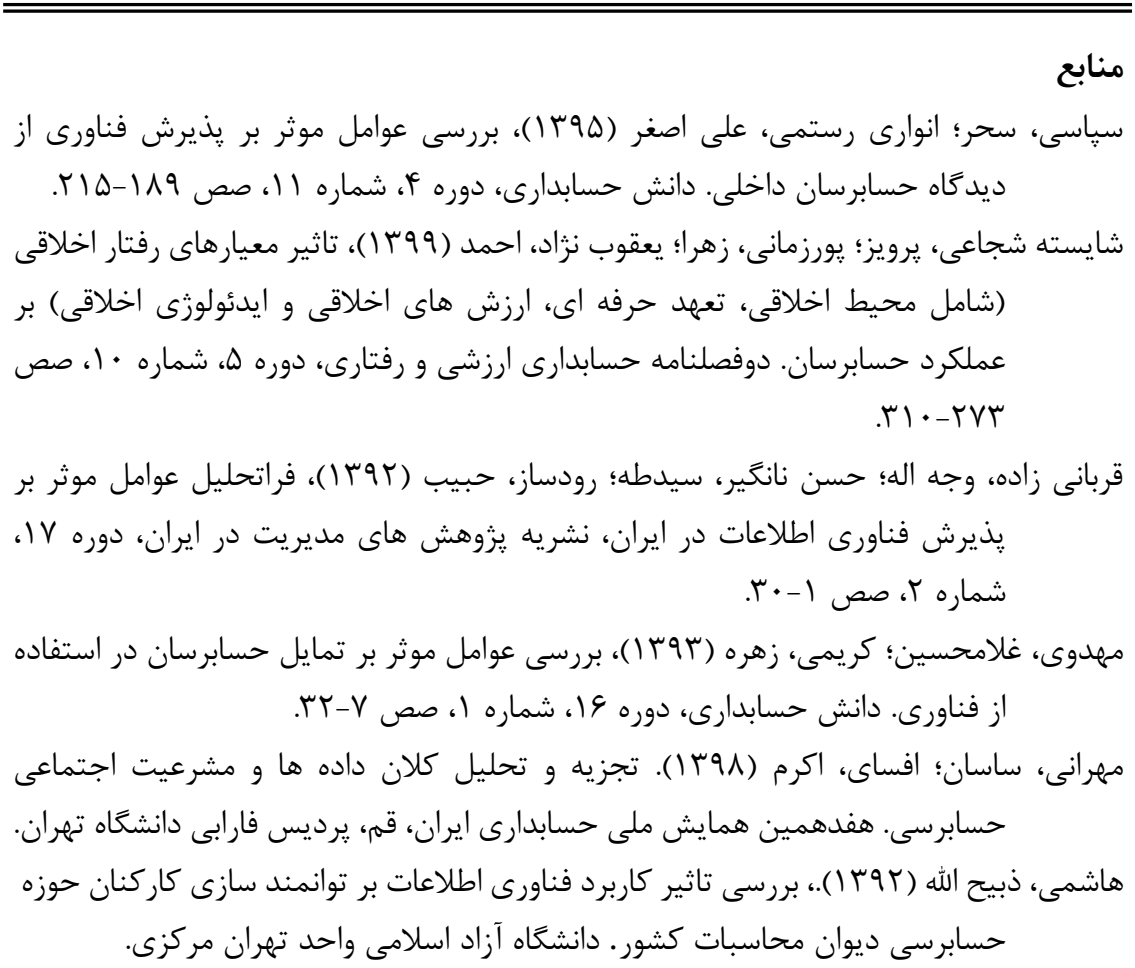

Ahmi, A., and S. Kent. 2013. The utilisation of generalized audit software (GAS). Managerial Auditing Journal 28(2): 88-113.

Anderson, S. F., K. Kelley, and S. E. Maxwell. 2017. Sample-size planning for more accurate statistical power: A method adjusting sample effect sizes for publication bias. Psychological Science 28(11): 1547-1562.

Al-Ansi, A. A., N.A. Bin Ismail, and A.K. Al-Swidi. 2013. The effect of IT knowledge and IT training on the IT utilization among external auditors: evidence from Yemen. Asian Social Science 9(10): 307-323.

Ajzen, I. 1991. The theory of planned behavior. Organizational Behavior and Human Decision Processes 211(50): 179-211.

Al-Hiyari, A. 2019. Factors That Influence the Use of Computer Assisted Audit Techniques (Caats) By Internal Auditors in Jordan. Academy of Accounting and Financial Studies Journal 23(3).

Baptista, G, and T. Oliveira. 2016. A weight and a meta-analysis on mobile banking acceptance. Computers in Human Behavior 63: 480-489.

Banker, R. D., H. Chang, and Y. Kao. 2002. Impact of information technology on public accounting firm productivity. Journal of Information Systems 16 (2): 209-222. 


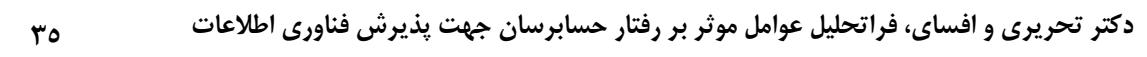

Bedard, J. C. 2003. The Roles of Task and Technical Knowledge in Acceptance of Information Technology Among Preparers and Reviewers of Audit Workpapers. Accessed on May 24th.

Bedard, J. C., C. Jackson., M. L. Ettredge, and K. M. Johnstone. 2003. The effect of training on auditors'acceptance of an electronic work system. International Journal of Accounting Information Systems 4(4):227250 .

Borenstein, M., L. V. Hedges., J. P. T. Higgins, and H. R. Rothstein. 2010. A basic introduction to fixed-effect and random-effects models for meta-analysis. Research Synthesis Methods 1(2): 97-111.

Bierstaker, J., D. Janvrin, and D.J. Lowe. 2014. What factors influence auditors' use of computer-assisted audit techniques? Adv. Account 30: $67-74$.

Bozkurt, O., and N. Çakmak, 2020. Teknoloji Kabul Modeli Perspektifinden Bağımsız Denetçilerin Bilgisayar Destekli Denetim Programlarını Kullanıma Iliş̧in Tutum Ve Davranışlarının Potansiyel Fayda Beklentisi Üzerine Etkisi, BMIJ 8(4): 607-646.

Bonsón, E., and C. Borrero. 2011. Analysis of the Factors Affecting the Adoption and Use of Continuous Audit Tools and Techniques: Comparison Between the Public and Private Sector. International Journal of Economics and Management Sciences 1(3): 8-16.

Cao, M., R. Chychyla, and T. Stewart. 2015. Big data analytics in financial statement audits. Accounting Horizons 29(2): 423-429.

Cook, T. D. 1991. Meta-analysis: Its potential for causal description and causal explanation within program evaluation. In W. de Gruyter (Ed.). Social prevention and the social sciences: Theoretical controversies, research problems, and evaluation strategies 245-285.

Curtis, M.B, and E.A. Payne. 2014. Modeling voluntary CAAT utilization decisions in auditing. Manag. Audit. J, 13 (4): 304-326.

Curtis, MB, and E.A. Payne. 2008. An examination of contextual factors and individual characteristics affecting technology implementation decisions in auditing. Int J Account Inf Syst 9(2):104-121.

Chafik, K., and H. Mghizou. 2018. Study of the acceptance and effect of audit automation software used by financial auditors on the legal mission. Information Systems Management \& Innovation 2(1).

Davis, FD., RP. Bagozzi, and PR. Warshaw. 1989. User acceptance of computer technology: a comparison of theoretical models. Manag

Dowling, C. 2009. Appropriate audit support system use: The infuence of auditor and audit team. The Accounting Review 84(3): 771-810.

DiMaggio, P., and WW. Powell. 1983. The iron cage revisited: Collective rationality and institutional isomorphism in organizational. American sociological review 48 (2): 147-160. 
Darmaningtyas, I. G. B., and K. A. Suardana. 2017. Pengaruh Technology Acceptance Model (TAM ) dalam Penggunaan Software Oleh Auditor yang Berimplikasi Pada Kinerja Auditor. E-Jurnal Akuntansi 21(21): 2448-2478.

Dharma, D.P.B., P.I. Sandhyaduhita., A.A. Pinem, and A.N. Hidayanto. 2017. Antecedents of intention-to-use of e-audit system: a case of the audit board of the republic of Indonesia. International Journal of Business Information Systems 26(2): 185-204.

Dolinsek, S, and A. Janes. 2008. Development of the Technology Audit Model. in Menagement International Conference of the Faculty of Management Koper, MIC.

Diaz, M.C., and T. Loraas. 2010. Learning new uses of technology while on an audit engagement: Contextualizing general models to advance pragmatic understanding, International Journal of Accounting Information Systems11: 61-77.

Daoud, L., A. Mareib., S.M. Al-Jabaly, and A. AldaaS. 2021. Moderating the role of top management commitment in usage of computer-assisted auditing techniques. Accounting 7: 457-468.

Ebimobowei, A., GN. Ogbonna, and P. Enebraye. 2013. Auditor's Usage of Computer Assisted Audit Tools and Techniques: Empirical Evidence from Nigeria. Research Journal of Applied Sciences, Engineering and Technology 6 (2): 187-95.

Fishbein, M, and I. Ajzen. 1975. Belief, Attitude, Intention and Behavior: An Introduction Theory. Reading, MA: Addison- Wesley.

Fembriyanto, S. B., Trisno, M., Manalu, G. (2019). The effect of perceived usefulness, perceived ease of use, and complexity upon the acceptance of computerized audit tehnique (ACAT) at the Finance and Development Supervisory Agency (FDSA) Republic of Indonesia. The Accounting Journal of BINANIAGA, 4 (1), 15-26.

Gonzalez, G., P.N. Sharma, and D. Galletta. 2012. The Antecedents of Internal Auditors' Adoption of Continuous Auditing Technology: Exploring UTAUT in an Organizational Context. 7th University of Waterloo Research Symposium on Information Integrity and Information Systems Assurance, Toronto, Canada.

Hamari, J., and J. Koivisto. 2015. Why do people use gamification services? International Journal of Information Management 35(4): 419-431.

Hamari, J, and L. Keronen. 2017. Why do people buy virtual goods: A metaanalysis. Computers in Human Behavior 71: 59-69.

Hunter, J. E, and F. L. Schmidt. 2014. Methods of meta-analysis: Correcting error and bias in research findings, Sage publications.

Higgins, J., S. Thompson., J. Deeks., and D. Altman. 2003. Measuring inconsistency in meta-analyses. BMJ 32 (14): 557-560. 


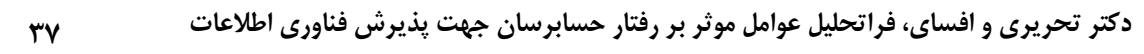

Huang, S. M., Y.-C. Hung., and H.-H Tsao. 2008. Examining the determinants of computer assisted audit techniques acceptance from internal auditors. International Journal of Services and Standards 4 (4): $377-$ 392.

Hasan, B. 2007. Examining the effects of computer self-efficacy and system complexity on technology acceptance. Information Resources Management Journal 20(3): 76-88.

Janvrin, D., J. Bierstaker., and D.J. Lowe. 2008, An examination of audit information technology use and perceived importance. Accounting Horizons 22(1): 1-21.

Janvrin, D., D.J. Lowe, and J. Bierstaker. 2009. Auditor acceptance of computer assisted audit techniques. American Accounting Association Auditing Mid Year Meeting AAA, St Petersburg, FL:1.

Khalil, A, B., and N. Olfa. 2020. Factors That Influence the Adoption of Computer Assisted Audit Techniques (CAATs) by External Auditors in Yemen. International Journal of Accounting and Financial Reporting 10(2): 2162-3082.

Karahanna, E., and D. W. Straub. 2001. The psychological origins of perceived usefulness and ease of-use. Information \& Management 35: 237-250.

King, W. R., J. He. 2006. A meta-analysis of the technology acceptance model. Information and Management 43(6): 740-755.

Kim, H. J., M. Mannino., and R.J. Nieschwietz. 2009. Information technology acceptance in the internal audit profession: impact of technology features. Int.J. Account. Inf. Syst 10: 214-228.

Kusumadewi, A. W. 2017. Study on auditor's attitude in using information technology for auditing: Theory of planned behavior and social cognitive theory modification. Russian Journal of Agricultural and Socio-Economic Sciences 6 (66): 602-617.

Lowe, D.J., J.L. Bierstaker., D.J. Janvrin, and J.G., Jenkins. 2018. Information technology in an audit context: have the big 4 lost their advantage?. J. Inf. Syst 32 (1): 87-107.

Li, H., J. Dai., T. Gershberg, and M. Vasarhelyi. 2018. Understanding usage and value of audit analytics for internal auditors: an organizational approach, International Journal of Accounting Information Systems 28: 59-76.

Lipsey, M.W., and D. B. Wilson. 2001. Practical meta-analysis. Applied Social Research Methods 49: 1-247.

Mahdavi, G., and M. Karimi. 2012. An Investigation in to Auditors' Tendency toward using IT Achievements: Independent Auditors' View. American Journal of Scientific Research 80: 54-61. 
Mahzan, N., and A. Lymer. 2008. Adoption of computer assisted audit tools and techniques (CAATs) by internal auditors: Current issues in the UK. Proceedings of the British Accounting Association Annual Conference, Blackpool, UK.

Martens, D., L. Bruynseels., B. Baesens., M. Willekens., and J. Vanthienen. 2014. Predicting going concern opinion with data mining. Decis. Support. Syst 45: 765-777.

Mansour, E. M. 2016. Factors Affecting the Adoption of Computer Assisted Audit Techniques in Audit Process: Findings from Jordan. Business and Economic Research 6(1): 248-271.

Payne, E. A., and M. B. Curtis. 2017. Factors Associated with Auditors' Intention to Train on Optional Technology. Curr. Issues Audit 11(1).

Pongpattrachai, D. 2010. The model of Infusion in small audit firms in Thailand. Thesis, University of Canterbury, Thailand.

Pedrosa, I., C. J. Costa., and M. Aparicio. 2019. Determinants adoption of computer-assisted auditing tools.Cognition, Technology and Work.

Pedrosa, I., C. J. Costa., and R. M. Laureano. 2015. Motivations and limitations on the use of information technology on statutory auditors' work: An exploratory study. In the 10th Iberian Conference on Information Systems and Technologies, IEEE, Aveiro, Portugal: 1-6.

Rana, N. P., Y. K. Dwivedi., and M. D. Williams. 2015. A meta-analysis of existing research on citizen adoption of e-government. Information Systems Frontiers 17(3): 547-563.

Ramen, M., B. Jugurnath, and P. Ramhit. 2015. UTR-CTOE: a new paradigm explaining CAATs adoption. J Mod Account Audit 11(12): 615-631.

Rogers, E.M. 1995. Diffusion of Innovations. Free Press, New York.

Rosli, K., P. H. Yeow., and E. G. Siew. 2012. Factors influencing audit technology acceptance by audit firms: A new I-TOE adoption framework. Journal of Accounting and Auditing.

Rosli, K., E. Siew., and P. H. P. Yeow. 2016. Technological, organisational and environmental aspects of audit technology acceptance. International Journal of Business and Management 11(5): 140-145.

Sari, D. P., and A. Rahman.2019. Analisis Faktor-Faktor yang Mempengaruhi Minat Pemanfaatan Teknologi Informasi bagi Auditor. Journal of Economic, Bussines and Accounting 2(2): 202-211.

Suryandini, D. 2010. Aplikasi model penerimaan teknologi dalam penggunaan software audit oleh duditor. Jurnal Dinamika Akuntansi 2(2): 92-102.

Siew, E.-G., K. Rosli., P.H.P. Yeow. 2019. Organizational and environmental influences in the adoption of computer- assisted audit tools, International Journal of Accounting Information Systems. 
دكتر تحريرى و افساى، فراتحليل عوامل موثر بر رفتار حسابرسان جهت يذيرش فناورى اطلاعات

Simon, B. 2001. Knowledge media in the education system: acceptance research in universities. WU Vienna University of Economics and Business: Wien, Austria 179.

Shihab, M.R., N. Meilatinova., and A.N. Hidayanto. 2018. determinants of CAATT acceptance: insights from public accounting firms in Indonesia. Proceeding of the 4th information systems international conference, Procedia Comput 522-529.

Tiberius, V., and S. Hirth. 2019. Impacts of Digitization on Auditing: A Delphi Study for Germany, Journal of International Accounting, Auditing and Taxation.

Tijani, O. M. 2014. Built-In Functions and Features of Data Analysis Software: Predictors of Optimal Deployment for Continuous Audit Assurance. Sch. J.Econ. Bus.Manag (1)1: 7-18.

Taherdoost, H. 2018. A review of technology acceptance and adoption models and theories. Procedia Manufacturing 22: 960-967.

Tao, D., W. Tieyan., W. Tieshan., Z. Tingru., Z. Xiaoyan., and Q. Xingda. 2019. A systematic review and meta-analysis of user acceptance of consumer-oriented health information technologies. Computers in Human Behavior.

Tornatzky, L. G., and M. Fleischer. 1990. The Processes of Technological Innovation. Lexington MA, Lexington Books.

Tangke, N. 2004. Analisa Penerimaan Penerapan Teknik Audit Berbantuan Komputer (TABK) dengan Menggunakan Technology Acceptance Model (TAM) pada Badan Pemeriksa Keuangan (BPK) RI. Jurnal Akuntansi Keuangan 6(1): 10-28.

Van Den Broek, T., and A.F. Van Veenstra. 2018. Governance of Big Data collaborations: how to balance regulatory compliance and disruptive innovation. Technol. Forecast. Soc. Change 129: 330-338.

Venkatesh, V., M G. Morris., GB. Davis., and FD. Davis. 2003. User acceptance of information technology: toward a unified view. MIS Quarterly 27(3): 425-478.

Vasarhelyi, M. A., and M. G. Alles. 2008. Reengineering business reporting creating a test bed for technology driven reporting.

Zhu, K., and K. L. Kraemer. 2005. Post-adoption variations in usage and value of e business by organisations: cross-country evidence from the retail industry. Information systems research 16(1): 61-84.

Widuri, R., B. L. Handoko, and I. C. Prabowo. 2019. Adoption of Information Technology in Public Accounting Firm. Proceedings of the 2019 4th International Conference on Big Data and Computing 198-202.

Widuri, R., B. O'Connell, and P.W. Yapa. 2016. Adopting generalized audit software: an Indonesian perspective. Manag. Audit. J 31 (8/9): 821847. 
Witte, A., C. Thibodeau, and Earley, E. 2020. Managing the Technological Revolution: How Audit Partners Nurture. Control, and Standardize Change. Electronic Journal 21(1). 